\title{
Improvements to the WRF-Chem 3.5.1 model for quasi-hemispheric simulations of aerosols and ozone in the Arctic
}

\author{
Louis Marelle ${ }^{1,2, a}$, Jean-Christophe Raut ${ }^{1}$, Kathy S. Law ${ }^{1}$, Larry K. Berg ${ }^{3}$, Jerome D. Fast ${ }^{3}$, Richard C. Easter ${ }^{3}$, \\ Manish Shrivastava ${ }^{3}$, and Jennie L. Thomas ${ }^{1}$ \\ ${ }^{1}$ LATMOS/IPSL, UPMC Univ. Paris 06 Sorbonne Universités, UVSQ, CNRS, Paris, France \\ ${ }^{2}$ TOTAL S.A, Direction Scientifique, Tour Michelet, 92069 Paris La Défense, France \\ ${ }^{3}$ Pacific Northwest National Laboratory, Richland, WA, USA \\ ${ }^{a}$ now at: Center for International Climate and Environmental Research, Oslo, Norway
}

Correspondence to: Louis Marelle (louis.marelle@cicero.oslo.no)

Received: 31 March 2017 - Discussion started: 8 May 2017

Revised: 26 August 2017 - Accepted: 31 August 2017 - Published: 9 October 2017

\begin{abstract}
In this study, the WRF-Chem regional model is updated to improve simulated short-lived pollutants (e.g., aerosols, ozone) in the Arctic. Specifically, we include in WRF-Chem 3.5.1 (with SAPRC-99 gas-phase chemistry and MOSAIC aerosols) (1) a correction to the sedimentation of aerosols, (2) dimethyl sulfide (DMS) oceanic emissions and gas-phase chemistry, (3) an improved representation of the dry deposition of trace gases over seasonal snow, and (4) an UV-albedo dependence on snow and ice cover for photolysis calculations. We also (5) correct the representation of surface temperatures over melting ice in the Noah Land Surface Model and (6) couple and further test the recent KFCuP (Kain-Fritsch + Cumulus Potential) cumulus parameterization that includes the effect of cumulus clouds on aerosols and trace gases. The updated model is used to perform quasi-hemispheric simulations of aerosols and ozone, which are evaluated against surface measurements of black carbon (BC), sulfate, and ozone as well as airborne measurements of $\mathrm{BC}$ in the Arctic. The updated model shows significant improvements in terms of seasonal aerosol cycles at the surface and root mean square errors (RMSEs) for surface ozone, aerosols, and BC aloft, compared to the base version of the model and to previous large-scale evaluations of WRF-Chem in the Arctic. These improvements are mostly due to the inclusion of cumulus effects on aerosols and trace gases in $\mathrm{KF}-\mathrm{CuP}$ (improved RMSE for surface $\mathrm{BC}$ and BC profiles, surface sulfate, and surface ozone), the improved surface temperatures over sea ice (surface ozone, BC, and sulfate), and the updated trace gas deposition and UV
\end{abstract}

albedo over snow and ice (improved RMSE and correlation for surface ozone). DMS emissions and chemistry improve surface sulfate at all Arctic sites except Zeppelin, and correcting aerosol sedimentation has little influence on aerosols except in the upper troposphere.

\section{Introduction}

The Arctic is one of the fastest warming regions on Earth (IPCC, 2013). Early studies have shown that 20th century Arctic warming was mostly a consequence of the increased concentration of well-mixed greenhouse gases (e.g., $\mathrm{CO}_{2}$ and $\mathrm{CH}_{4}$ ), associated with the effect of shorter-lived climate forcers, especially aerosols and ozone (Shindell et al., 2006). As a result, mitigating Arctic warming requires first and foremost global reductions of carbon emissions. However, controlling short-lived species could be a faster and more costeffective way to limit Arctic and global warming, while also improving air quality (e.g., Stohl et al., 2015), since aerosols and ozone are also harmful air pollutants.

Global climate and chemistry-transport models are key tools used to understand the past and future roles of shortlived pollutants. However, modeling aerosol and ozone pollution in the Arctic has proven very challenging in the past. Studies by Shindell et al. (2008), Koch et al. (2009), and Schwarz et al. (2010) have shown that most models at the time strongly underestimated black carbon (BC) observed at the Arctic surface, and overestimated it aloft. In addition, 
models often failed to reproduce the observed seasonal cycle of surface aerosol pollution, which peaks in late winter and early spring due to enhanced transport from the midlatitudes and lower deposition efficiencies (Quinn et al., 2007). Studies have since shown that these model biases were likely caused by the limited horizontal resolution (Sato et al., 2016; Raut et al., 2017), missing local emission sources (Stohl et al., 2013), and poorly known removal processes. Specifically, Huang et al. (2010), Liu et al. (2012), Browse et al. (2012), and Wang et al. (2013) showed that Arctic BC could be improved by the use of more complex aerosol wet removal schemes within models. However, implementing these schemes does not fully resolve model disagreement with BC measurements (Browse et al., 2012; Wang et al., 2014; Eckhardt et al., 2015; Schwarz et al., 2017), and recent research (Mahmood et al., 2016) indicates that differences in wet scavenging efficiencies are still the main cause of differences in Arctic BC burdens between models.

Concerning ozone, Emmons et al. (2015), Monks et al. (2015), and Arnold et al. (2015) showed that most models exhibit strong biases in ozone precursors such as nitrogen oxides $\left(\mathrm{NO}_{x}\right)$, carbon monoxide $(\mathrm{CO})$, peroxyacetyl nitrate (PAN) and several oxygenated volatile organic compounds (VOCs), and underestimate ozone in the middle and high Arctic troposphere by $\sim 10$ to $30 \%$. Similarly, results from the AMAP (2015) model intercomparison indicate that models are strongly biased in the Arctic for both ozone and its precursors. These biases are attributed to uncertainties in emissions, pollution transport and processing, overestimated stratosphere-troposphere exchange and uncertainties related to the hydroxyl radical $\mathrm{OH}$.

The main known causes of model error in the Arctic (except emissions) can in theory be addressed by using regional models, for which global coverage can be traded for increased process complexity and higher resolutions. Several recent case studies have shown the validity of this approach, by using the regional WRF-Chem model (Weather Research and Forecasting model, including chemistry; Grell et al., 2005; Fast et al., 2006) in order to understand the effect of local pollutant emissions from shipping at high latitudes (Mölders et al., 2010; Marelle et al., 2016) and the mechanisms of pollution transport from the midlatitudes to the Arctic (Sessions et al., 2011; Thomas et al., 2013; Marelle et al., 2015; Raut et al., 2017). However, these case studies were based on short, relatively local simulations, while Arctic pollution transported from the midlatitudes can only be studied using long, quasi-hemispheric simulations, which can resolve both remote and local sources of Arctic pollution. Such a quasi-hemispheric WRF-Chem simulation was performed for the first time and evaluated in the intercomparisons of Eckhardt et al. (2015) and AMAP (2015). Unfortunately, in spite of its good performance for local case studies, WRF-Chem performed poorly in terms of aerosols (Eckhardt et al., 2015), failing to reproduce observed aerosol concentrations and their seasonal evolution in spring and summer 2008. AMAP (2015) showed that WRF-Chem performs reasonably well for ozone, but other research (Ahmadov et al., 2015) indicates that the version of WRF-Chem used in AMAP (2015) can be strongly biased low for ozone over snow-covered ground due to overestimated dry deposition and underestimated photolysis rates. In this context, the main objectives of this study are to improve WRF-Chem results for Arctic aerosols and ozone compared to the previous large-scale model intercomparisons of Eckhardt et al. (2015) and AMAP (2015), to identify potential areas of further improvements in the WRF-Chem model, and to define a model setup that can be used in future work to study aerosol and ozone pollution on continental scales in the Arctic, defined in this study as the region north of $60^{\circ} \mathrm{N}$.

The model setup and emissions are presented in Sect. 2. Section 3 presents how the WRF-Chem 3.5.1 model was updated for this study. The effect of these updates on Arctic aerosols and ozone is evaluated in Sect. 4, where results are also validated against surface and airborne measurements in the Arctic. Conclusions are presented in Sect. 5.

\section{WRF-Chem}

WRF-Chem (Grell et al., 2005; Fast et al., 2006) is a regional meteorological, chemistry, and aerosol model based on the mesoscale meteorological model WRF-ARW (Advanced Research WRF; Skamarock et al., 2008). WRF-Chem is fully integrated within WRF, and uses the same grid, time step, advection scheme, and physics schemes as WRF. The developments presented in this study (presented in Sect. 3) are based on the version 3.5.1 of the model (the current version in March 2017 is 3.8.1 and only includes two of the updates presented here, Sect. 3). The version used here also includes the additions to WRF-Chem 3.5.1 related to the KF-CuP cumulus scheme and described in Berg et al. $(2013,2015)$.

\subsection{Model setup, domain, and simulation period}

The model setup is presented in Table 1. Briefly, the gasphase chemistry mechanism is SAPRC-99 (Statewide Air Pollution Research Center, 1999 version; Carter, 2000). Photolysis rates used in the gas-phase chemistry calculations are calculated by the Fast-J scheme (Wild et al., 2000). Aerosols are represented by the MOSAIC (Model for Simulating Aerosol Interactions and Chemistry; Zaveri et al., 2008) model, with eight size bins between $39 \mathrm{~nm}$ and $10 \mu \mathrm{m}$. The version of the SAPRC-99-MOSAIC-8bin mechanism used here includes bulk aqueous chemistry, as well as secondary organic aerosol (SOA) formation represented by the VBS2 (volatility basis set with two volatility species; Shrivastava et al., 2011) scheme, treating the partitioning of organic aerosols between the volatile and the condensed phase using the "volatility basis set" approach (Robinson et al., 2007). In this study, VBS-2 only includes SOA formation from the oxi- 
Table 1. WRF-Chem 3.5.1 setup.

\begin{tabular}{ll}
\hline Option name & Selected option \\
\hline $\begin{array}{l}\text { Chemistry and aerosol options } \\
\text { Gas-phase chemistry }\end{array}$ & $\begin{array}{l}\text { SAPRC-99 (Carter, 2000) } \\
\text { Aerosols }\end{array}$ \\
$\begin{array}{l}\text { MOSAIC } 8 \text { bins (Zaveri et al., 2008) } \\
\text { + VBS-2 SOA formation and aqueous chemistry } \\
\text { Photolysis }\end{array}$ & Fast-J (Wild et al., 2000) \\
\hline Meteorological options & \\
\hline Planetary boundary layer & MYJ (Janjić, 1994) \\
Surface layer & Monin-Obukhov Janjić Eta scheme (Janjić, 1994) \\
Land surface & Unified Noah land surface model (Chen and Dudhia, 2001) \\
Microphysics & Morrison (Morrison et al., 2009) \\
SW radiation & RRTMG (Iacono et al., 2008) \\
LW radiation & RRTMG (Iacono et al., 2008) \\
Cumulus parameterization & KF-CuP (Berg et al., 2015) \\
\hline
\end{tabular}

dation of anthropogenic and biogenic VOCs. SOA formation from semi-volatile and intermediate-volatility organic compounds (SVOCs and IVOCs) was not included due to its high computational cost and due to the lack of accurate global SVOC and IVOC emission inventories.

The MYJ (Mellor-Yamada-Janjić) scheme is used to represent the planetary boundary layer, with the associated Janjić Eta surface layer scheme (Janjić, 1994). The land surface is represented using the Noah LSM (unified Noah land surface model; Chen and Dudhia, 2001). Radiative calculations are performed using the RRTMG scheme (Rapid Radiative Transfer Model for Global applications; Iacono et al., 2008), which is coupled here with WRF-Chem-predicted ozone and aerosol optical properties. The recommended microphysical scheme to be used with MOSAIC is the Morrison twomoment scheme (Morrison et al., 2009). The Morrison twomoment scheme calculates cloud formation, cloud properties, and precipitation on the grid scale, as well as aerosol activation in clouds, aqueous chemistry for activated aerosols, and wet removal. Subgrid clouds are represented using the KF-CuP (Kain-Fritsch + Cumulus Potential) parameterization developed by Berg et al. (2013). KF-CuP is a convective parameterization based on the Kain-Fritsch (Kain and Fritsch, 1990; Kain, 2004) cumulus scheme and the cumulus potential (Berg and Stull, 2005) scheme. The version of KF-CuP implemented in WRF-Chem (Berg et al., 2015) also represents the effect of cumulus clouds on aerosols and trace gases (additional details are given in Sect. 3.1).

Initial and boundary conditions for meteorology, as well as sea-surface temperatures (SSTs) and sea ice, are specified using NCEP FNL (National Center for Environmental Prediction, final analysis); boundary conditions, SSTs, and sea ice are updated every $6 \mathrm{~h}$. In addition, WRF-Chem winds, temperature and humidity are nudged to the FNL analysis in the free troposphere (grid nudging) with the same $6 \mathrm{~h}$ update time. Initial and boundary conditions for chemistry are taken from the global model MOZART-4 (Model for Ozone and Related chemical Tracers; Emmons et al., 2010), and also updated every $6 \mathrm{~h}$. The simulation domain (polar stereographic projection) is presented in Fig. 1. It includes remote sources of pollution potentially transported to the Arctic in less than 30 days (Stohl, 2006), a transport time larger than the mean ozone and aerosol lifetimes in the troposphere (22 days and less than 10 days, respectively). Simulations are performed for the period from 1 March to 1 August 2008, in order to include both a period with active long-range pollution transport to the Arctic (March to early May) and a period when pollution removal processes are more prevalent (late May to July). The month of March is discarded as spin-up. In order to be computationally feasible, simulations are run at a relatively low horizontal resolution of $100 \mathrm{~km} \times 100 \mathrm{~km}$, which is, however, 2 to 3 times finer than the typical resolutions used by most global models investigating Arctic aerosol and ozone (Eckhardt et al., 2015; Emmons et al., 2015). Simulations are performed for the year 2008, when many measurement datasets are available as part of the POLARCAT (Polar Study using Aircraft, Remote Sensing, Surface Measurements and Models, Climate, Chemistry, Aerosols and Transport; Law et al., 2014) project, and to allow comparison with the WRF-Chem simulation presented in Eckhardt et al. (2015) and AMAP (2015).

\subsection{Emissions}

Anthropogenic emissions are from the ECLIPSEv5 dataset (Evaluating the Climate and Air Quality Impacts of ShortLived Pollutants; Klimont et al., 2017), except shipping emissions from RCP8.5 (Representative Concentration Pathway 8.5; Riahi et al., 2011). The ECLIPSEv5 inventory includes BC emissions from gas flaring in the Russian Arctic, which have been shown to improve the representation of Arctic BC by Stohl et al. (2013). Fire emissions are 


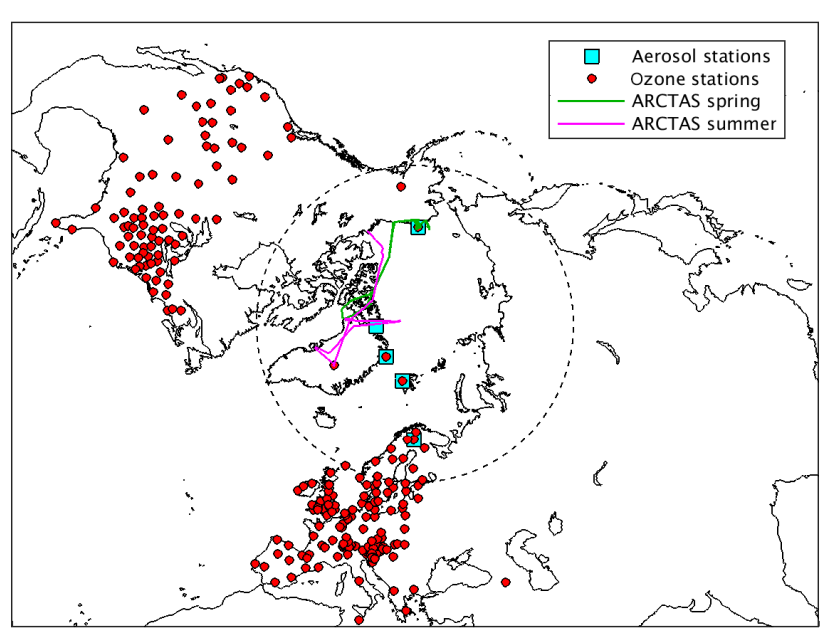

Figure 1. WRF-Chem simulation domain and location of the measurements used in this study. Stations measuring ozone are shown as red circles. Arctic aerosol measurement sites (BC and sulfate) are shown as blue squares. ARCTAS spring and summer flight tracks north of $70^{\circ} \mathrm{N}$ (as in Eckhardt et al., 2015) are shown in green and pink, respectively.

from FINNv1.5 (Fire INventory from NCAR, Version 1.5; Wiedinmyer et al., 2014). Soil NO emissions are from the POLMIP (POLARCAT Model Intercomparison Project) inventory (Emmons et al., 2015). Biogenic emissions from vegetation are calculated online by the MEGAN model (Model of Emissions of Gases and Aerosols from Nature; Guenther et al., 2006). Other emissions calculated online by the WRF-Chem model include sea salt, mineral dust (both from the GOCART model; Chin et al., 2002), and lightning $\mathrm{NO}_{x}$ emissions (Wong et al., 2013).

\section{Improvements included in WRF-Chem 3.5.1}

We identify several processes previously missing from the WRF-Chem model version 3.5.1 and potentially important for the representation of Arctic aerosols and ozone. This section presents the model updates included and evaluated in this study. (1) We include the effect of cumulus on aerosols and trace gases as represented in the KF-CuP cumulus scheme within WRF-Chem (Sect. 3.1). KF-CuP is used here, but it was included in WRF-Chem 3.5.1 in Berg et al. (2013) and Berg et al. (2015) and released in later WRFChem versions; it is here further coupled to other components of the model and its impacts on Arctic aerosols and ozone are evaluated. Updates developed specifically for this study include (2) the addition of sedimentation aloft in the MOSAIC aerosol model (Sect. 3.2), (3) the inclusion of DMS emissions and gas-phase chemistry in the SAPRC-99 gasphase mechanism (Sect. 3.3), (4) the coupling of WRF snow to the dry deposition scheme (Sect. 3.4), (5) the inclusion of a dependence of UV albedo on snow and ice cover in the
Fast-J photolysis scheme (Sect. 3.5), and (6) the added heat sink from melting sea ice in calculations of the surface energy budget in the Noah-LSM surface model (Sect. 3.6). The updates presented in this section, except the KF-CuP scheme and the corrections to the Noah-LSM module, are not yet included in the latest version of WRF-Chem (3.8.1).

The different simulations performed to evaluate these updates are presented in Table 2. ALL_UPDATES is the reference simulation with all updates implemented, and NO_UPDATES a simulation where all updates presented in this section are turned off. We also perform simulations where each update is removed, leaving all of the others switched on (e.g., NO_SEDIMENTATION). The NO_KFCUP_CHEM simulation does not disable the KF$\mathrm{CuP}$ cumulus scheme entirely, but rather only its impacts on trace gases and aerosols (aerosol activation, aqueous chemistry, tracer transport, wet removal). Due to limited computational resources, the updates related to deposition and photolysis over snow are only evaluated separately (i.e., NO_SNOWDEP and NO_SNOWPHOT) for the months of March and April, when snow cover is highest, but are evaluated together (i.e., NO_SNOWDEP_SNOWPHOT) for the full study period (March-July).

This section presents these previously missing processes in more detail, their relevance to Arctic short-lived pollutants, and how they were taken into account in the WRFChem 3.5.1 model. The effect of these changes on Arctic aerosols and ozone are evaluated and discussed in Sect. 4.

\subsection{KF-CuP cumulus scheme and its effects on aerosols and trace gases}

Aerosol-cloud and trace gas-cloud interactions in the MOSAIC aerosol model, including wet removal and aqueous chemistry, were previously only represented in WRF-Chem for grid-scale (resolved) clouds, but not for cumulus (parameterized) clouds. Berg et al. (2015) recently included the KF$\mathrm{CuP}$ cumulus scheme in WRF-Chem 3.5.1, and modified it to take into account the effect of cumuli on aerosols and trace gases in the model. Specifically, the KF-CuP scheme within WRF-Chem represents the impacts of warm cumulus clouds on trace gas and aerosol vertical transport, activation and resuspension of aerosols, aqueous chemistry in clouds, wet removal of aerosol and trace gases, and impacts of aerosol activation on cloud droplet concentrations. Based on simulations in June 2007 in the southern United States, Berg et al. (2015) showed that using KF-CuP could decrease columnintegrated $\mathrm{BC}$ by up to $50 \%$, due to changes in wet removal, and increase $\mathrm{SO}_{4}^{2-}$ by up to $40 \%$ in nonprecipitating conditions, due to aqueous chemistry in clouds. However, neither the long-term or large-scale effect of using KF-CuP nor its effect on ozone has yet been investigated. These processes are very relevant for the Arctic, where most of the pollution is known to originate from long-range transport (Rahn, 1981; Law et al., 2014), and wet removal is the main process 
Table 2. Simulation list and description.

\begin{tabular}{ll}
\hline Simulation name & Description \\
\hline ALL_UPDATES & All model updates included \\
NO_KFCUP_CHEM & No effect of cumulus on aerosols and trace gases in the KF-CuP scheme \\
NO_SEDIMENTATION & No aerosol sedimentation above the first model level \\
NO_DMS & No dimethyl sulfide (DMS) emissions or gas-phase chemistry \\
NO_SNOWDEP & No reduced dry deposition of gases over snow (March-April only) \\
NO_SNOWPHOT & No increased UV albedo over snow and ice (March-April only) \\
NO_SNOWDEP_SNOWPHOT & Combination of NO_SNOWDEP and NO_SNOWPHOT (March-July) \\
NO_NOAH_SEAICE & No heat sink from melting sea ice in the Noah LSM \\
NO_UPDATES & All updates above turned off \\
\hline
\end{tabular}

controlling aerosol transport to the Arctic (Mahmood et al., 2016; Raut et al., 2017).

The version of KF-CuP used in this study includes secondary activation of aerosols above the cloud base, which was not included in Berg et al. (2015), and primary activation at cloud base. For primary activation, the model calculates the maximum supersaturation using the Abdul-Razzak and Ghan (2000) parameterization, with the cloud-base updraft speeds from KF-CuP, and the simulated aerosol concentrations in the updrafts. Secondary activation assumes a fixed maximum supersaturation of $0.1 \%$. Aerosol activation is then calculated from the maximum supersaturations and the critical supersaturations for each aerosol size bin. In addition, $\mathrm{KF}-\mathrm{CuP}$ is coupled here to the RRTMG radiation scheme, by passing the KF-CuP cloud fraction, cloud water, cloud ice, and cloud droplet numbers to RRTMG, following the approach of Alapaty et al. (2012). The lightning $\mathrm{NO}_{x}$ emissions scheme of Wong et al. (2013), previously coupled in WRF-Chem to other cumulus schemes, is also coupled here with $\mathrm{KF}-\mathrm{CuP}$, by linking KF-CuP cloud top heights, cloud fractions, and deep or shallow convection flags to the emission scheme. In this study, we only evaluate the effect of $\mathrm{KF}-\mathrm{CuP}$ on aerosols and trace gases. These effects are evaluated by disabling in KF-CuP the effect of cumuli on tracer transport, aerosol activation, aqueous chemistry, and wet removal (NO_KFCUP_CHEM simulation). The effect of lightning $\mathrm{NO}_{x}$ emissions or of the coupling between cumuli and radiation are not evaluated separately here, since they were already studied with other cumulus schemes in Wong et al. (2013) and Alapaty et al. (2012).

\subsection{Aerosol sedimentation aloft in the MOSAIC module}

In MOSAIC, as it is included in WRF-Chem (and up to the current version 3.8.1 in March 2017), aerosol sedimentation is only implemented in the lowest model level and only takes into account the contribution of sedimentation to dry deposition, but not its role in bringing particles from higher altitudes to the surface. This is discussed but not corrected in Ma et al. (2014). This could be an issue in longer, large-scale simulations, since this could lead to a build-up of large particles (e.g., dust), for which sedimentation is one of the main sinks (Tegen and Fung, 1994). In this study, a first-order explicit sedimentation scheme is implemented above the first vertical level in MOSAIC, using the same algorithm for calculating settling velocities as the one already in use for sedimentation at the model surface. The effects of this change are evaluated by performing a simulation without sedimentation aloft, called NO_SEDIMENTATION; results are discussed in Sect. 4.1.1.

\subsection{DMS emissions and gas-phase chemistry for SAPRC-99-MOSAIC}

The SAPRC-99-MOSAIC mechanism does not originally include dimethyl sulfide (DMS) gas-phase chemistry in WRF-Chem 3.5.1, even though DMS is known to be an important source of $\mathrm{SO}_{2}$ and sulfate in the Arctic during summer (Li and Barrie, 1993). Here, a simplified representation of $\mathrm{SO}_{2}$ chemical production from DMS is implemented in SAPRC-99, following the work of Emmons et al. (2010) and Chin et al. (1996). We also use the "online" DMS emission scheme in WRF-Chem, based on Nightingale et al. (2000) and Saltzman et al. (1993), as it was implemented in Marelle et al. (2016). For this study, this scheme is refined by using monthly resolved maps of oceanic DMS from the climatology of Lana et al. (2011) instead of a single oceanic DMS concentration value as in Marelle et al. (2016).

The effects of these updates are evaluated by performing a simulation without DMS chemistry or emissions, called NO_DMS; impacts on aerosols and ozone are discussed in Sect. 4, but we show here in Fig. 2 how this update changes surface DMS and $\mathrm{SO}_{2}$ in June-July 2008. The modeled amounts and geographical distribution are similar to previous studies (e.g., Boucher et al., 2003). DMS concentrations are especially elevated at higher latitudes due to the high oceanic DMS concentrations. As a result, DMS is also a major source of $\mathrm{SO}_{2}$, the main precursor for sulfate aerosols (Sect. 4.1.3), over the open Arctic ocean: away from Arctic shipping lanes, DMS emissions and gas-phase chemistry are responsible for 90 to $100 \%$ of surface $\mathrm{SO}_{2}$ in this region. 

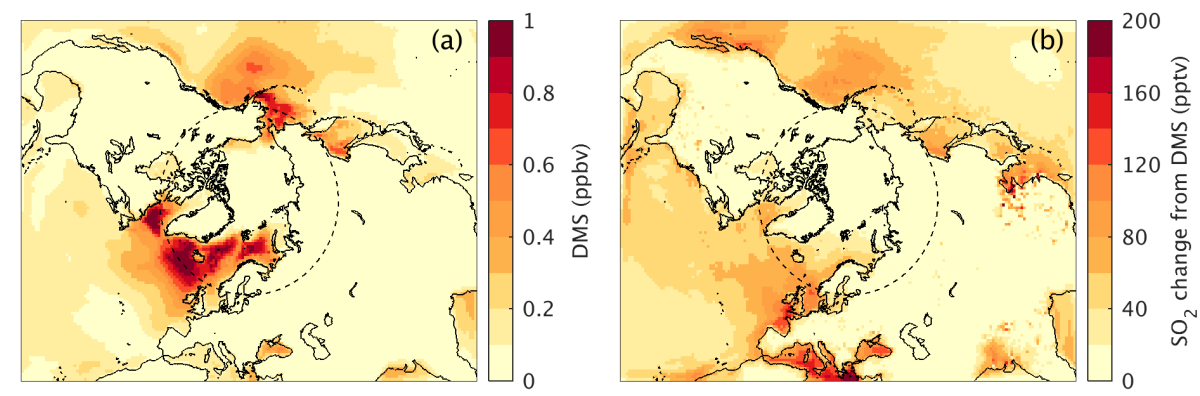

Figure 2. June-July average (a) DMS surface mixing ratios and (b) $\mathrm{SO}_{2}$ surface mixing ratios due to the implementation of DMS emissions and gas-phase chemistry in the model (ALL_UPDATES - NO_DMS).

\subsection{Coupling dry deposition of trace gases with predicted snow}

Dry deposition of trace gases is known to be lower in winter and over snow, due to the reduced stomatal uptake of gases by plants, and due to the enhanced atmospheric stability over snow, i.e., increased surface and aerodynamic resistance to deposition. Reduced deposition over seasonal snow cover was already taken into account for the MOZART gas-phase chemistry mechanism in WRF-Chem's deposition scheme (Wesely, 1989), but not for other mechanisms (e.g., SAPRC99, CBM-Z, RACM). For these other mechanisms, the model only took into account reduced deposition over permanently snow-covered surfaces (e.g., mountain tops) or over sea ice. As a result, Ahmadov et al. (2015) showed that WRF-Chem (run with RACM chemistry) could underestimate observed ozone by more than $5 \mathrm{ppbv}$ in wintertime conditions in the western United States.

In this study, we also correct WRF-Chem's dry deposition scheme for the SAPRC-99 mechanism, by forcing wintertime conditions in the dry deposition scheme ("Winter, snow on ground and near freezing" seasonal category in WRFChem; Wesely, 1989) when predicted snow height is above $10 \mathrm{~cm}$, the threshold already in use in WRF-Chem for the MOZART gas-phase chemistry mechanism. Over the snowcovered surfaces that were previously treated as vegetationcovered, this update reduces ozone deposition velocities by as much as $-0.25 \mathrm{~cm} \mathrm{~s}^{-1}$ during April, as shown in Fig. 3 .

\subsection{UV albedo over snow and ice in the Fast-J photolysis scheme}

In their study of high wintertime ozone pollution events in the western US, Ahmadov et al. (2015) also identified that the photolysis schemes implemented in WRF-Chem 3.5.1 were only using one single value for broadband UV albedo at the surface, 0.055 , even though this value should be much higher over snow or ice (up to 0.85). In order to correct this, Ahmadov et al. (2015) changed the broadband UV albedo to 0.85 in their simulations, the value measured at the site of their study. This value cannot be used as such here, since it

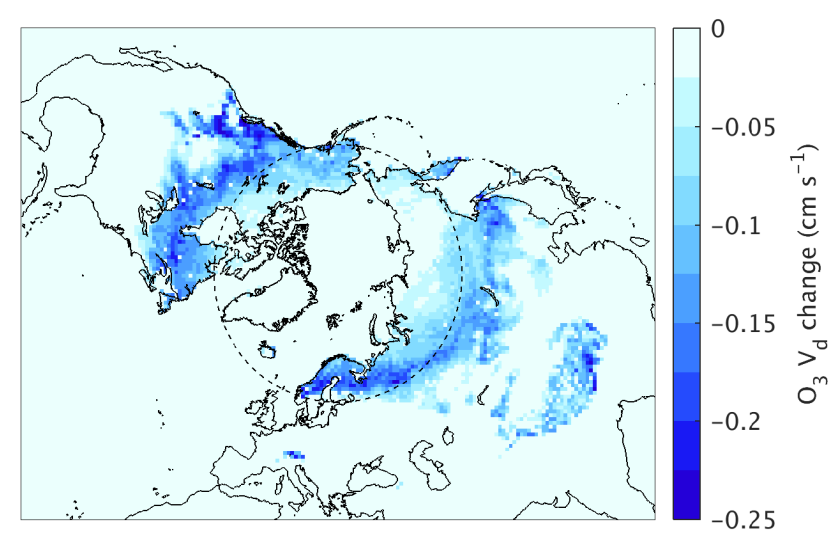

Figure 3. Change in ozone deposition velocity due to the implementation of wintertime dry deposition over seasonal snow (April 2008 average, ALL_UPDATES - NO_SNOWDEP).

corresponds to conditions of very high snow cover over bare ground, which are not representative of our whole simulation region.

Here, the UV albedo in the Fast-J photolysis scheme (Barnard et al., 2010) is calculated as an average (weighted by snow and ice cover) of the snow-free (or ice-free) albedo and the snow-covered (or ice-covered) albedo. This value is updated at each call of the photolysis scheme. Land-usedependent UV-albedo values over snow are taken from the satellite-derived dataset presented in Tanskanen and Manninen (2007) and are retrieved from a look-up table (Table 2 in Tanskanen and Manninen, 2007), based on the WRF-Chem land use category in each grid cell. The resulting UV-albedo values are much higher than the base value of 0.055 , up to 0.85 over $100 \%$ sea ice or bare snow cover. As a result, photolysis rates predicted by the Fast-J scheme are also greatly increased over snow- and ice-covered regions in April, by +50 to $+200 \%$ for $j \mathrm{O}^{1} \mathrm{D}$ and $j \mathrm{NO}_{2}$ (Fig. 4). The combined effect on surface ozone of this change and of reduced dry deposition over snow are validated and discussed in Sect. 4.2.1 and 4.2.2. 

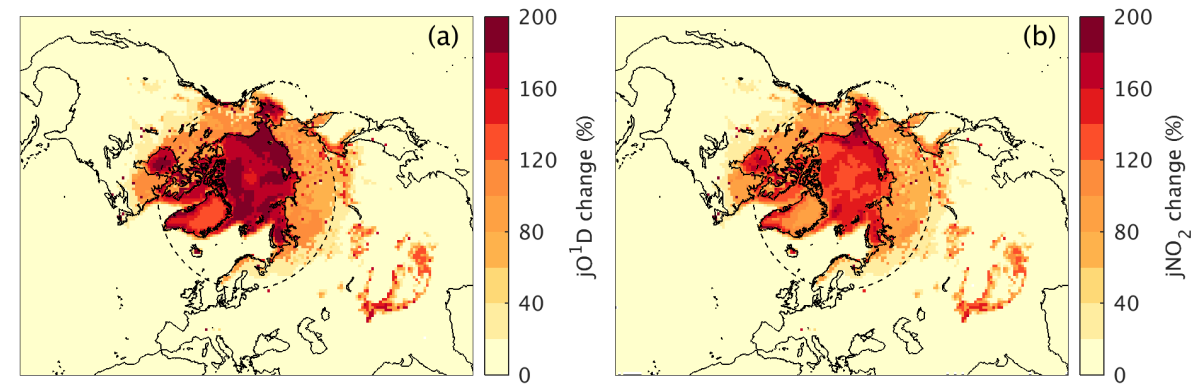

Figure 4. Change in (a) $j \mathrm{O}^{1} \mathrm{D}$ and (b) $j \mathrm{NO}_{2}$ photolysis rates at the surface due to the implementation of an UV-albedo dependence on snow and ice cover in the Fast-J scheme (April 2008 average, ALL_UPDATES - NO_SNOWPHOT).

\subsection{Heat sink from melting sea ice in the Noah land surface model}

In WRF version 3.5.1, the Noah land surface model did not take into account the heat sink due to sea-ice melt (latent heat of ice melt) in the energy budgets at the prescribed sea-ice surface. As a result, the surface model could predict unrealistically high surface temperatures during the ice-melt season. We corrected this issue by simply prescribing the skin temperature of sea ice to $0 \mathrm{~K}$ when the model diagnoses surface melt. We have shared this update with the WRF community, and it was included in WRF-Chem after version 3.7.1. Implementing this correction can decrease $2 \mathrm{~m}$ temperatures over sea ice by as much as $10 \mathrm{~K}$ during the melt season. This is of concern since the temperature contrast between snow and sea-ice-covered and snow- and sea-ice-free areas is one of the main factors determining the location of the Arctic dome (Stohl, 2006; Klonecki et al., 2003), whose northward retreat during summer isolates the Arctic surface from pollution transported from the midlatitudes. As a result, erroneously small latitudinal temperature contrasts could greatly increase long-range pollution transport to the Arctic surface during summer. However, the exact magnitude of this effect on Arctic aerosols and ozone has not been evaluated until now (this is discussed and validated in Sect. 4).

\section{Effect of the model updates on aerosol and ozone concentrations in the Arctic}

This section presents the effect of individual model updates on modeled aerosols (Sect. 4.1.1) and ozone (Sect. 4.2.1) in the Arctic. The new, updated version of the model is also validated against airborne (Sect. 4.1.2) and surface (Sect. 4.1.3 and 4.2.2) measurements of aerosols and ozone in the Arctic in 2008. Simulation performance is evaluated in terms of root mean square error (RMSE), defined as

$$
\frac{1}{n} \sqrt{\sum_{i=1}^{n}\left(x_{\mathrm{mod}, i}-x_{\mathrm{obs}, i}\right)^{2}}
$$

where $x_{\mathrm{mod}}$ and $x_{\mathrm{obs}}$ are the modeled and observed mass concentrations or volume mixing ratios, respectively.

\subsection{Aerosols}

\subsubsection{Effect on zonal mean aerosol concentrations in the Arctic}

The effect of the KFCUP_CHEM, SEDIMENTATION, NOAH_SEAICE, and DMS updates on zonal mean total aerosol mass concentrations (which are equivalent to zonal mean $\mathrm{PM}_{10}$ in WRF-Chem with MOSAIC) is presented in Fig. 5. The effect of the updated trace gas deposition and photolysis over snow and ice (SNOWDEP, SNOWPHOT) on $\mathrm{PM}_{10}$ (not shown) is very low, less than $1 \%$. Figure 5 shows that aerosol sedimentation aloft (SEDIMENTATION) and cumulus effects on aerosols and trace gases (KFCUP_CHEM) have the largest impact on aerosols in the Arctic, $-30 \%$ at higher altitudes. Sedimentation aloft is both a sink (particles transported below) and a source (particles transported from above) of particles at lower altitudes, which explains why it has little effect below $3 \mathrm{~km}$. The net effect of $\mathrm{KF}-\mathrm{CuP}$ is to decrease aerosol mass; this indicates that the effect is dominated by increased wet removal, as in Berg et al. (2015), and is not compensated for by increased sulfate formation in the aqueous phase (cloud chemistry) or by increased vertical aerosol precursor and aerosol transport (tracer convection).

The implementation of the sea-ice-melt heat sink in the Noah LSM strongly reduces $\mathrm{PM}_{10}$ at the Arctic surface $(<-20 \%)$, and increases aerosol concentrations aloft. In these simulations, local sources of pollution at the sea-ice surface are negligible; because of this, aerosol concentrations there are mostly due to downward mixing of aerosols and gases from the free troposphere. The NOAH_SEAICE updates reduce surface temperatures over sea ice during summer, increasing stability, decreasing vertical mixing, and thus reducing this tropospheric source (sink) of surface (free troposphere) pollution. DMS emissions and chemistry increase $\mathrm{PM}_{10}$ by +2 to $+4 \%$, due to increased $\mathrm{SO}_{4}^{2-}$ aerosols formed from $\mathrm{SO}_{2}$ in the marine boundary layer. However, 

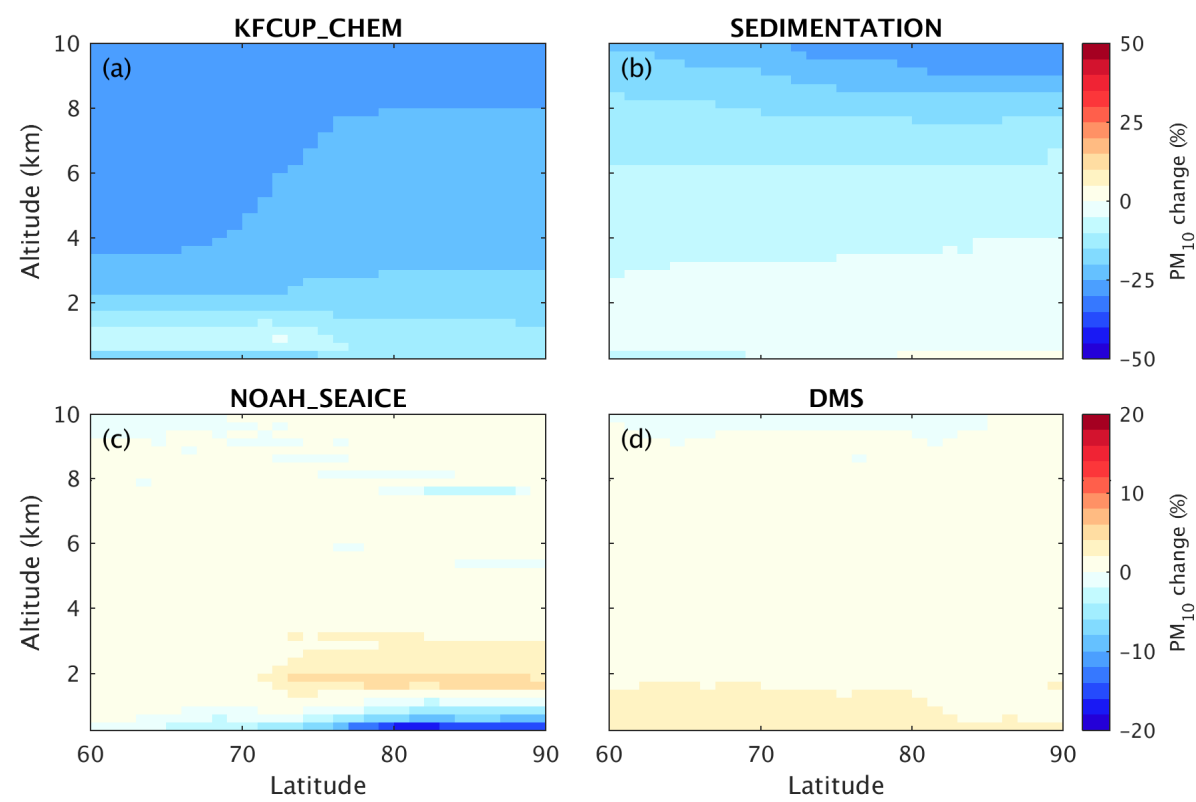

Figure 5. Change in the April-July 2008 average zonal mean $\mathrm{PM}_{10}$ due to (a) KF-CuP cumulus effect on aerosols and trace gases, (b) aerosol sedimentation aloft, (c) the sea-ice-melt heat sink in the Noah LSM, and (d) DMS emissions and chemistry. Note the differences in scale between top and bottom panels.

relative increases of $\mathrm{PM}_{10}$ from DMS remain rather low because of the relative lack of open water for DMS emissions north of $60^{\circ} \mathrm{N}$, and the high background $\mathrm{PM}_{10}$ in these areas due to colocated emissions of sea salt aerosols.

\subsubsection{Validation against BC profiles from the ARCTAS aircraft campaign}

In order to validate the modeled aerosol distribution, we compare in Fig. 6 results from the ALL_UPDATES and NO_UPDATES simulations to vertical profiles of refractory BC (rBC) measured by a SP2 (single-particle soot photometer) during the ARCTAS (Arctic Research of the Composition of the Troposphere from Aircraft and Satellites) campaigns in April and July 2008 (Jacob et al., 2010; Matsui et al., 2011). As in Eckhardt et al. (2015), this comparison only includes observations and model results north of latitude $70^{\circ} \mathrm{N}$. The updated model is in much better agreement with observations than the original NO_UPDATES simulation, especially in the summer, where RMSE decreases by $13.8 \mathrm{ng} \mathrm{m}^{-3}$ in ALL_UPDATES. Table 3 shows that the decreased model error is almost solely due $\left(-12.6 \mathrm{ng} \mathrm{m}^{-3}\right)$ to the KFCUP_CHEM update. Other updates have little effect, which is understandable since small BC-containing particles have slow sedimentation velocities, are not directly affected by DMS, and because the NOAH_SEAICE update has the largest effect at the sea-ice surface, which was not sampled by the aircraft. The updates have little effect on correlation coefficients, which rise from 0.07 to 0.08 in spring, and decrease from 0.48 to 0.43 during summer, indicating that nei- ther the base model nor the updated version is able to reproduce well the vertical variability of BC in the Arctic troposphere. In addition, the updated model still overestimates observations in summer, which could be due to overestimated emissions from, for example, biomass burning, or underestimated removal. Raut et al. (2017) showed that increasing the horizontal resolution from 100 to $40 \mathrm{~km}$ could reduce summertime BC simulated by WRF-Chem by $25-30 \%$, by improving the representation of wet removal.

\subsubsection{Validation against surface measurements of $\mathrm{BC}$ and $\mathrm{SO}_{4}^{2-}$ in the Arctic}

WRF-Chem simulation results are evaluated in Fig. 7 against surface equivalent $\mathrm{BC}(\mathrm{eBC})$ and non-sea-salt sulfate measurements in the Arctic. The eBC is calculated based on light absorption measurements by particle soot absorption photometers (PSAPs) and converted to concentrations by assuming a value for mass-absorption efficiency. As a result, the uncertainty in $\mathrm{eBC}$ measurement is of at least a factor of 2 (Bond et al., 2013). $\mathrm{SO}_{4}^{2-}$ is obtained from filters and analyzed by ion chromatography. The contribution from sea salt is removed to obtain a non-sea-salt sulfate concentration comparable with WRF-Chem aerosol sulfate. Additional details about these measurements are given in Eckhardt et al. (2015).

In terms of BC, the updated model run (ALL_UPDATES) agrees much better with surface $\mathrm{eBC}$ measurements than the NO_UPDATES simulation, especially during summer (decreasing RMSE by $-8.8 \mathrm{ng} \mathrm{m}^{-3}$ ). Table 3 shows that this 

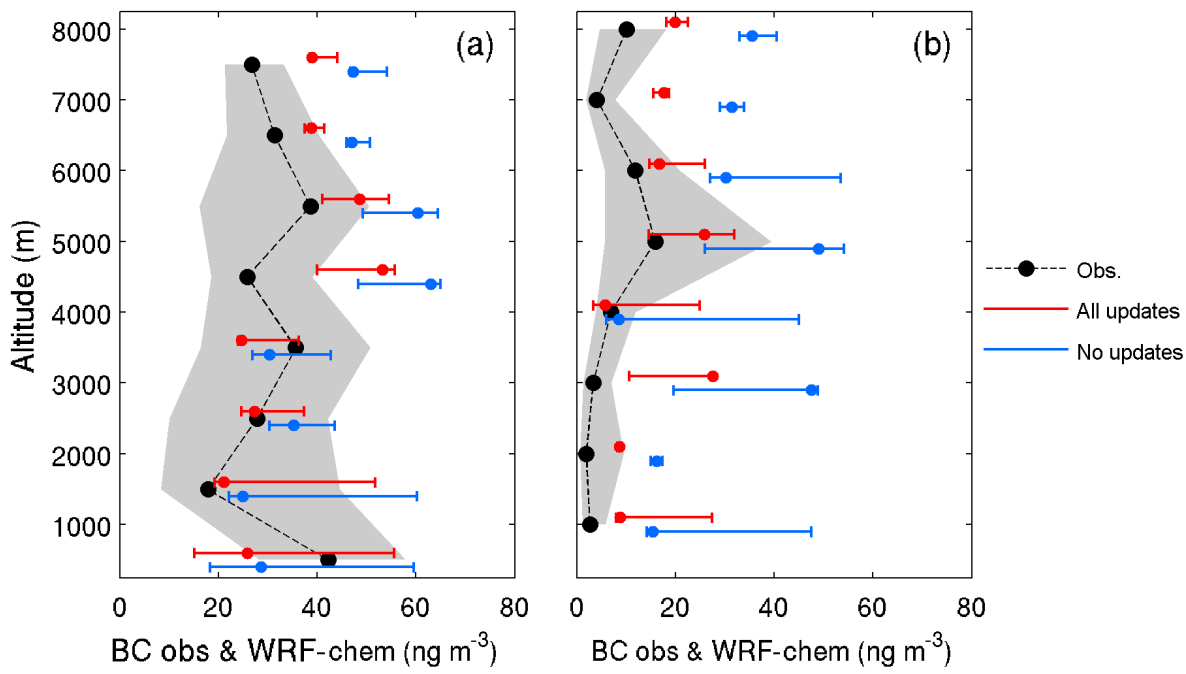

Figure 6. ARCTAS (a) spring and (b) summer median SP2 $\mathrm{rBC}$ (size range 90-1000 nm) profiles north of latitude $70^{\circ} \mathrm{N}$ (gray shading indicates 25th and 75th percentiles) and WRF-Chem median BC (size range $80-1000 \mathrm{~nm}$ ) profiles interpolated along the same ARCTAS flights (red, ALL_UPDATES; blue, NO_UPDATES; error bars indicate 25th and 75th percentiles).

Table 3. RMSE of individual WRF-Chem simulations relative to Arctic observations of aerosols and ozone. All sensitivity simulations are performed by deactivating updates from the ALL_UPDATES simulation; as a result, any increase in RMSE relative to ALL_UPDATES indicates that a given update improved RMSE. For surface measurements, RMSEs are calculated at each station and given as a network average.

\begin{tabular}{lrrrrr}
\hline Simulation name & $\begin{array}{r}\text { ARCTAS spring BC } \\
\left(\mathrm{ng} \mathrm{m}^{-3}\right)\end{array}$ & $\begin{array}{r}\text { ARCTAS summer BC } \\
\left(\mathrm{ng} \mathrm{m}^{-3}\right)\end{array}$ & $\begin{array}{r}\text { Surface BC } \\
\left(\mathrm{ng} \mathrm{m}^{-3}\right)\end{array}$ & $\begin{array}{r}\text { Surface } \mathrm{SO}_{4} \\
\left(\mathrm{ng} \mathrm{m}^{-3}\right)\end{array}$ & $\begin{array}{r}\text { Surface } \mathrm{O}_{3} \\
\left(\mathrm{ppbv}^{2}\right)\end{array}$ \\
\hline ALL_UPDATES & 13.5 & 11.6 & 14.2 & 261 & 7.56 \\
NO_UPDATES & 18.8 & 25.4 & 23.0 & 332 & 8.89 \\
NO_SEDIMENTATION & 13.6 & 11.7 & 14.5 & 270 & 7.56 \\
NO_KFCUP_CHEM & 18.7 & 24.2 & 17.6 & 285 & 7.97 \\
NO_NOAH_SEAICE & 13.4 & 11.6 & 16.8 & 309 & 7.54 \\
NO_DMS & 13.5 & 11.3 & 14.4 & 263 & 7.61 \\
NO_SNOWDEP_SNOWPHOT & 13.5 & 11.6 & 14.4 & 279 & 8.35 \\
AMAP(2015) and Eckhardt et al. (2015) & 13.8 & 38.8 & 34.8 & 493 & 9.4 \\
\hline
\end{tabular}

is mostly due to the implementation of the KFCUP_CHEM $\left(-3.4 \mathrm{ng} \mathrm{m}^{-3}\right.$ of RMSE) and NOAH_SEAICE $\left(-2.6 \mathrm{ng} \mathrm{m}^{-3}\right.$ of RMSE) updates, other updates having very little effect $\left(<0.3 \mathrm{ng} \mathrm{m}^{-3}\right.$ change in RMSE). The average Pearson correlation coefficient increases from 0.43 to 0.87 , indicating that the seasonal cycle of $\mathrm{BC}$ pollution is also improved in the model.

For sulfate, the updated model performs much better at Alert and Barrow during summer, and slightly better at other stations, due to the competing effects of increased sulfate from DMS and decreased sulfate from KFCUP_CHEM and NOAH_SEAICE. Surprisingly, DMS has relatively little effect on the $\mathrm{SO}_{4}^{2-}$ RMSE on average (Table 3). This is because including DMS emissions and gas-phase chemistry improves RMSE at Pallas (Finland), Alert (Canada), Nord (Greenland), and Barrow (Alaska) ( -11 to $-27 \mathrm{ng} \mathrm{m}^{-3}$ ) but degrades RMSE at Zeppelin (Svalbard) $\left(+66 \mathrm{ng} \mathrm{m}^{-3}\right)$, where the model already overestimates sulfate. Another surprising result is the impact of dry deposition and UV-albedo updates on sulfate (Table 3 ). This effect is likely mediated by changes in oxidants $(\mathrm{OH}$ and ozone, as discussed in Sect. 4.2.1) and their impacts on $\mathrm{SO}_{2}$ oxidation. These updates also improve the modeled seasonal cycle of sulfate, increasing the average Pearson correlation coefficient from 0.28 to 0.73 . Both NO_UPDATES and ALL_UPDATES tend to be biased low in April (especially at the most remote Arctic sites, Alert, Barrow, and Nord), which could be due to underestimated long-range transport caused by the limited resolution (Sato et al., 2016). 

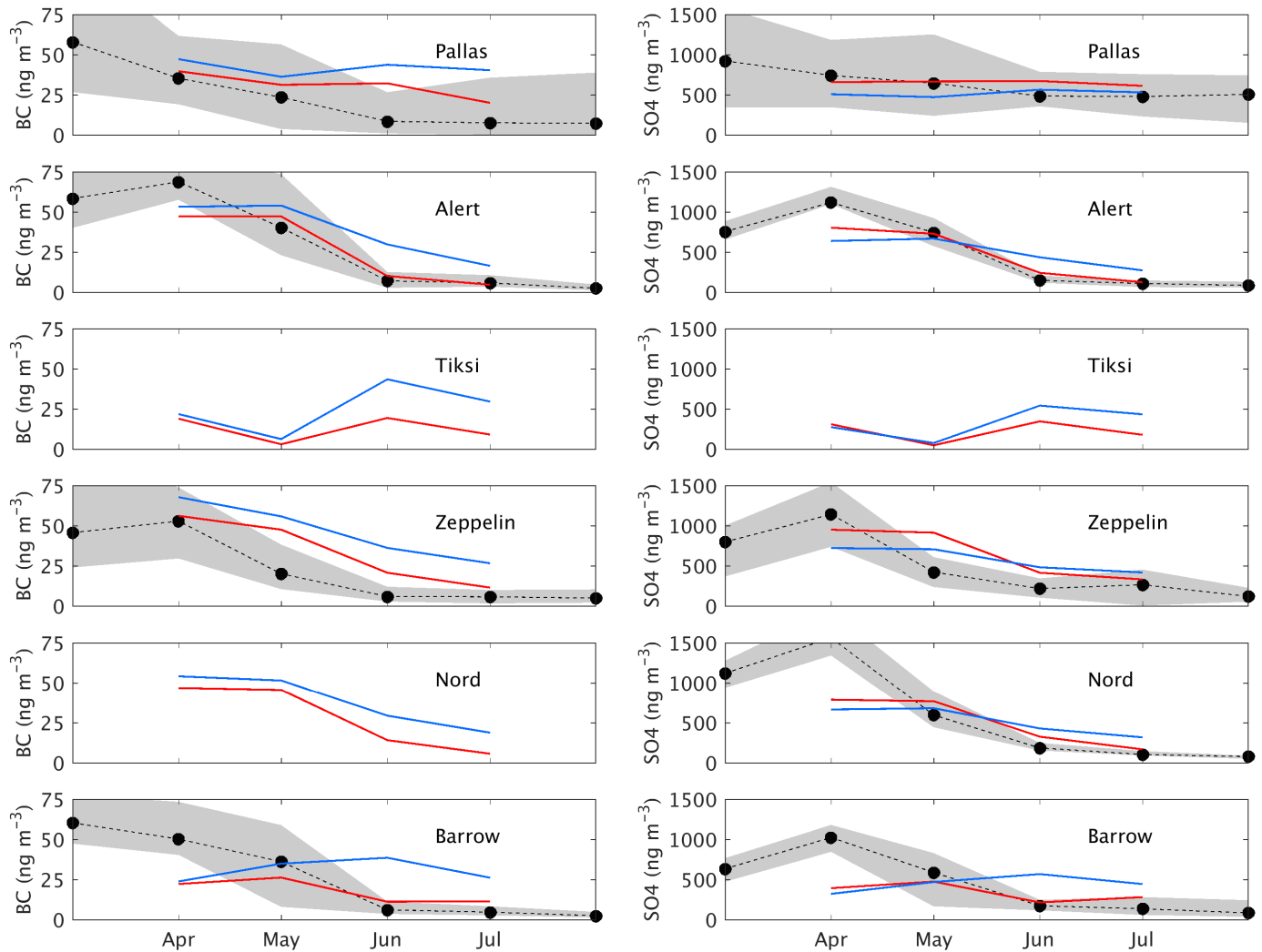

(a)

-... Obs. - All updates

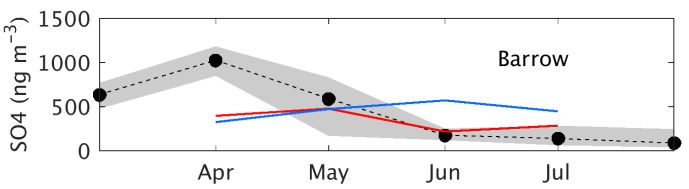

(b)

Figure 7. Monthly median $\mathrm{BC}$ (left) and $\mathrm{SO}_{4}^{2-}$ (right) observations at Arctic surface stations (gray shading indicates 25 th and 75 th percentile) and corresponding WRF-Chem results (red, ALL_UPDATES; blue, NO_UPDATES).

\subsection{Ozone}

\subsubsection{Effect on surface ozone in the Arctic}

The effect of the SNOWDEP_SNOWPHOT, NOAH_SEAICE, KFCUP_CHEM, and DMS updates on surface $\mathrm{O}_{3}$ concentrations in the Arctic is shown in Fig. 8 . The effect of aerosol sedimentation aloft (SEDIMENTATION) on ozone is very low and is not shown. The updates related to deposition and photolysis over frozen surfaces have a strong effect on surface $\mathrm{O}_{3}$. Based on the 1-monthlong simulations NO_SNOWDEP and NO_SNOWPHOT in April, we find that this is mostly due to changes in dry deposition $(+10 \mathrm{ppbv}$ in April, against +1 to $+2 \mathrm{ppbv}$ for photolysis). Ozone also decreases slightly over sea ice with the SNOWDEP_SNOWPHOT update. This is likely due to the UV flux increase from the SNOWPHOT update, since ozone formation in the Arctic boundary layer is $\mathrm{NO}_{x}$-limited (Jacob et al., 1992), and ozone increases when the UV flux decreases in $\mathrm{NO}_{x}$-limited regions (Liu and Trainer, 1988). Ozone concentrations at the surface are strongly reduced by the NOAH_SEAICE update (down to $-10 \mathrm{ppbv}$ ), due to the increased stability and lower influx of ozone precursors and ozone from the free troposphere to the surface. The
KFCUP_CHEM update also has a strong effect on ozone $(+2$ to $+5 \mathrm{ppbv})$, especially at lower latitudes where convection occurs. This could be due to tracer transport by midlevel convective clouds, bringing polluted air down to the surface (Lelieveld and Crutzen, 1994). Adding DMS leads to a modest decrease in surface ozone over the open ocean ( -2 ppbv at most), which is associated with a decrease in $\mathrm{NO}_{x}$ mixing ratios $(-10$ to $-20 \%)$, due to an increased $\mathrm{HNO}_{3}$ sink $(+5$ to $+20 \%)$ from increased $\mathrm{N}_{2} \mathrm{O}_{5}$ uptake on the additional sulfate aerosols $\left(-20\right.$ to $-90 \% \mathrm{~N}_{2} \mathrm{O}_{5}$ at the sea surface).

\subsubsection{Validation against surface measurements of ozone in the midlatitudes and in the Arctic}

WRF-Chem results from the ALL_UPDATES and NO_UPDATES simulations are evaluated against surface ozone measurements from the EMEP (European Monitoring and Evaluation Programme) European network and the CASTNET (Clean Air Status and Trends Network) US network, in addition to ozone measurements from the Barrow (Alaska) and Summit (Greenland) polar observatories of NOAA-ESRL (National Oceanic and Atmospheric Administration, Earth System Research Laboratory). The 
KFCUP_CHEM

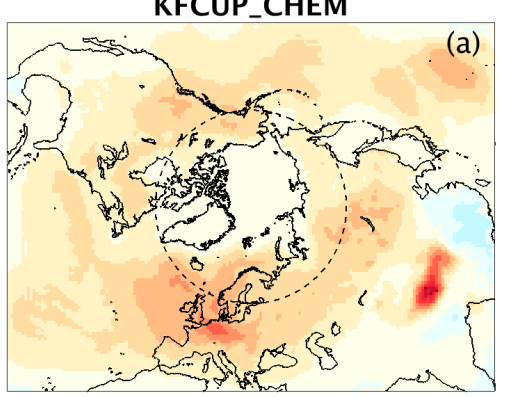

NOAH_SEAICE

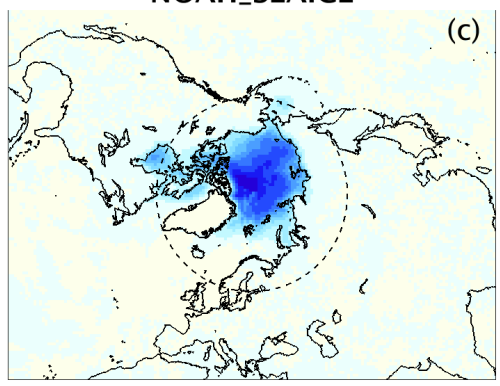

SNOWDEP_SNOWPHOT

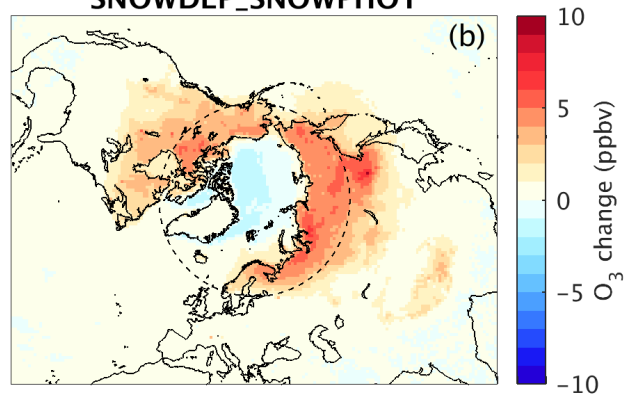

DMS

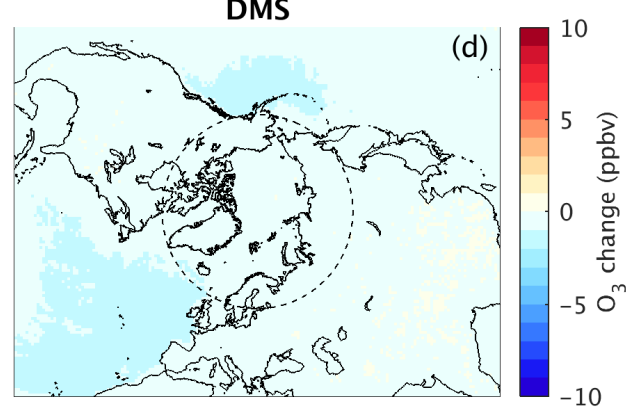

Figure 8. Change in the April to July average surface ozone due to (a) KF-CuP cumulus effect on aerosol and trace gases, (b) improved trace gas deposition over snow and improved UV albedo for photolysis over snow and ice, (c) sea-ice-melt heat sink in the Noah LSM, and (d) DMS emissions and gas-phase chemistry.

evaluation against Arctic stations (north of $60^{\circ} \mathrm{N}, 17$ out of 228 stations) is shown in Fig. 9b. When all updates are included, RMSE is reduced for all seasons $(-1.3 \mathrm{ppbv}$ on average), even though the ALL_UPDATES simulations sometimes overestimate ozone in spring. This overestimation is clearly due to the fact that WRF-Chem has no treatment of halogen chemistry in the model, which is responsible for ozone depletion events in polar regions during spring (e.g., Simpson et al., 2007; Abbatt et al., 2012). Table 3 shows that improvements in RMSE are mostly due to the SNOWDEP_SNOWPHOT update $(-0.8 \mathrm{ppbv}$ RMSE) and to the KFCUP_CHEM update $(-0.4 \mathrm{ppbv}$ RMSE). The average Pearson correlation coefficient also increases from 0.67 to 0.73 in the updated model, only due to the SNOWDEP_SNOWPHOT update. The effect of the NOAH_SEAICE update is low, since only stations Nord in northern Greenland and Barrow in Alaska are located in an area with significant summer sea ice, where this change affecting surface mixing ratios could play a role. Figure 9 shows that these updates also have a relatively strong effect over the whole measurement network, including subarctic sites, indicating that these processes should also be taken into account when studying ozone at lower latitudes with WRF-Chem. At subarctic sites (south of $60^{\circ} \mathrm{N}$ ), model updates decrease RMSE by $13 \%$ on average, and by more than $50 \%$ at nine surface sites. These improvements in the midlatitudes are mostly due to the KFCUP_CHEM update, and to the SNOWDEP_SNOWPHOT update at sites where
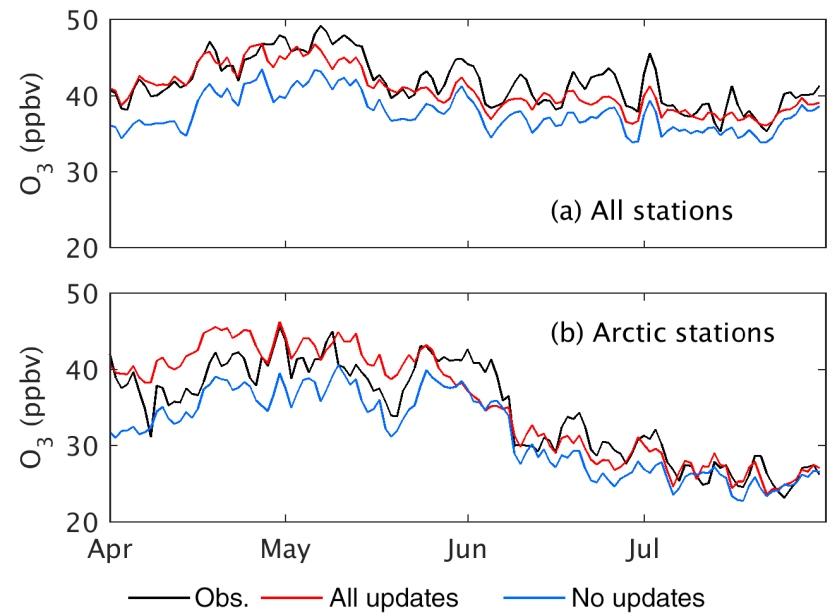

Figure 9. Comparison between daily averaged surface ozone measurements (black) and WRF-Chem results (red, ALL_UPDATES; blue, NO_UPDATES) (a) averaged over all stations within the domain (228 stations) and (b) averaged over Arctic stations only (latitude $>60^{\circ} \mathrm{N}, 17$ out of 228 stations).

seasonal snow is present. Ahmadov et al. (2015), using WRF-Chem 3.5.1, also showed that reduced deposition and enhanced photolysis over snow could contribute to high wintertime ozone in the United States, when other favorable conditions were present, such as shallow boundary layers and high emissions. 


\subsection{Discussion about the differences with the quasi-hemispheric WRF-Chem simulation in Eckhardt et al. (2015) and AMAP (2015)}

The ALL_UPDATES simulation performs better than the WRF-Chem 3.5.1 simulation presented in Eckhardt et al. (2015) and AMAP (2015). Compared to these earlier results, RMSE is improved in ALL_UPDATES by $0.3 \mathrm{ng} \mathrm{m}^{-3}$ for ARCTAS Spring rBC, by $27.2 \mathrm{ng} \mathrm{m}^{-3}$ for ARCTAS summer $\mathrm{rBC}$, by $20.6 \mathrm{ngm}^{-3}$ for surface $\mathrm{BC}$, by $232 \mathrm{ng} \mathrm{m}^{-3}$ for surface $\mathrm{SO}_{4}^{2-}$, and by $1.84 \mathrm{ppbv}$ for surface ozone (Table 3). However, the NO_UPDATES simulations also perform better than the simulation in Eckhardt et al. (2015) and AMAP (2015), compared to most datasets (RMSE higher by $5.0 \mathrm{ng} \mathrm{m}^{-3}$, lower by $13.4 \mathrm{ng} \mathrm{m}^{-3}$, lower by $11.8 \mathrm{ng} \mathrm{m}^{-3}$, lower by $161 \mathrm{ng} \mathrm{m}^{-3}$, and lower by $0.51 \mathrm{ppbv}$, respectively). This indicates that the model updates presented here are only partly responsible for this improved RMSE, and that differences in setup between the simulations also play a large role.

There are many differences in model setup between the simulation in Eckhardt et al. (2015) and AMAP (2015) and the ones presented here. The most significant are (1) the change of the gas-phase chemistry scheme (SAPRC-99 here and CBM-Z earlier, but both being coupled to MOSAIC-8 bin aerosols including aqueous chemistry); (2) the different fire emission inventories (daily FINNv1.5 emissions here, monthly GFEDv3.1, Global Fire Emissions Database, emissions earlier); (3) the larger simulation domain used here, extending down to latitudes $10-35^{\circ} \mathrm{N}$ (Fig. 1), instead of 28 $45^{\circ} \mathrm{N}$ earlier; and (4) the inclusion of lightning $\mathrm{NO}_{x}$ emissions here. Although it is difficult to attribute precisely the improvement to each of these changes, the change in fire emissions likely had a strong effect on modeled BC, since we find that GFEDv3.1 BC emissions north of $60^{\circ} \mathrm{N}$ used in earlier WRF-Chem simulations were 1.5 and 3.9 times higher in June and July than FINNv1.5 BC emissions used here, a point also discussed in AMAP (2015). Another likely driver of errors for aerosols is the relatively small simulation domain used earlier. This could have made WRF-Chem results too dependent on the lateral boundary conditions from the MOZART-4 global model, in which aerosols are represented by a simpler bulk aerosol scheme. The change of gas-phase mechanism, the use of a lightning $\mathrm{NO}_{x}$ emissions scheme, and the larger simulation domain used here also likely had an impact on ozone results in the Arctic.

\section{Conclusions}

In this study, we update the WRF-Chem 3.5.1 model (with SAPRC-99 gas-phase chemistry and MOSAIC aerosols) and perform quasi-hemispheric simulations of aerosols and ozone in the Arctic region. This allows us to draw the following main conclusions and perspectives:
1. Improved aerosols and ozone simulated by WRFChem 3.5.1 in the Arctic. Updating the model greatly reduces model errors compared to previous WRF-Chem evaluations in the Arctic (e.g., Eckhardt et al., 2015). Specific simulations with and without each model update allow us to characterize which process has the most effect on Arctic pollution distributions. Simulated airborne and surface BC in the Arctic is particularly sensitive to the effect of cumulus clouds on aerosols and trace gases (wet removal, aerosol activation, tracer transport, and cloud chemistry, represented by the KF$\mathrm{CuP}$ scheme) and to the representation of skin temperatures over sea ice, affecting stability, in the Noah land surface model. Implementing these two updates, as well as DMS gas-phase chemistry, also improves the representation of sulfate concentrations in the Arctic, although the simple DMS chemistry scheme used here appears to overestimate sulfate production at one Arctic site (Zeppelin). In our simulations, neglecting sedimentation aloft does not have a significant impact on BC or sulfate concentrations and has relatively little influence on total aerosol concentrations, except in the upper troposphere. Model updates also improve simulated ozone, both in the Arctic and in the midlatitudes. The corrections to skin temperatures in the Noah LSM have a strong impact on ozone over sea ice ( -5 to $-10 \mathrm{ppbv})$, while the implementation of KF-CuP increases ozone by +2 to +5 ppbv both in the Arctic and at lower latitudes. The main source of improvement over land appears to be the implementation of a snow- and icedependent UV albedo for the Fast-J photolysis scheme, and the decrease in deposition velocities over snowcovered ground $(>+10$ ppbv combined effect in spring where seasonal snow is present, in the Arctic and in the midlatitudes). However, implementing these processes can sometimes degrade model performance in the Arctic spring, by increasing ozone levels already overestimated because of the lack of halogen chemistry in the gas-phase mechanism.

2. Identification of potential areas of further improvement in the WRF-Chem model. The main discrepancies between modeled and observed ozone in the Arctic occur in spring at coastal Arctic sites (e.g., Barrow, Alert, Nord), where ozone depletion by halogen chemistry occurs. In order to study springtime Arctic ozone it seems critical to include these processes in WRF-Chem, as discussed earlier, e.g., in AMAP (2015). WRF-Chem underestimates aerosol surface concentrations in spring, which could be due to underestimation of long-range transport due to the limited horizontal resolution. Ma et al. (2013) found little improvement in $\mathrm{BC}$ transport when decreasing the resolution from 2 to $1^{\circ}$, but recent research (Sato et al., 2016) indicates that $\mathrm{BC}$ transport to the Arctic could be enhanced in WRF- 
Chem simulations at much finer resolutions $(<10 \mathrm{~km})$. Simulations with the updated model have significantly lower RMSE for airborne BC during summer $(-54 \%)$, but the model still significantly overestimates BC aloft in this season. This could also be due to the low resolution or to underestimated removal processes (Raut et al., 2017), since the model does not currently represent aerosol activation in ice clouds and only includes a simplified treatment of secondary activation in deep convective clouds. Emissions from boreal fires could also be an important source of uncertainty during summer, and for this reason it is important to validate the different fire emission inventories in the Arctic.

\section{Definition of a model setup that can be used in future} work to study aerosol and ozone pollution on continental scales in the Arctic. The updated model setup presented in this paper improves simulation of BC, sulfate, and ozone in the Arctic. The updated results now appear to be in better agreement than most global models included in the recent intercomparisons of Eckhardt et al. (2015) and AMAP (2015), although further model intercomparisons are needed to confirm this. There are many pressing issues concerning short-lived pollutants in the Arctic and their climate impacts which require reliable model results on the hemispheric scale. For example, the relative importance of the different pollution sources to Arctic pollution is still uncertain (local vs. remote, fossil fuel vs. biomass burning, natural vs. anthropogenic). In addition, the attribution of recent trends in Arctic composition can be difficult if long-range transport from different source regions is not correctly reproduced. Other Arctic issues could also benefit from accurate large-scale regional simulations, such as the impact of Arctic air pollution on ecosystems (i.e., through deposition) and a more precise quantification of the climate impacts of cloud-aerosol interactions in the Arctic and of BC deposition on snow (Arnold et al., 2016).

Code availability. The WRF-Chem code is available at http: //www2.mmm.ucar.edu/wrf/users/download/get_source.html. After version 3.8, it includes the KF-CuP scheme and, after version 3.7.1, the sea-ice correction in the Noah-LSM module presented in this paper. Other updates will be proposed for implementation in the next WRF-Chem version or can be obtained from Louis Marelle (louis.marelle@cicero.oslo.no) upon request.

Author contributions. The first author (LM) developed and implemented the updates, performed the simulations and the analysis, and drafted the paper. JCR, KSL, and JLT contributed to simulation design, to the interpretation of results, and to writing the paper. The WRF-Chem 3.5.1 code with latest KF-CuP and SOA developments was provided by PNNL authors (JDF, LKB, RCE, MS), who also advised on how to perform further coupling between WRF-Chem and the KF-Cup code (LKB, RCE) and how to simplify the SOA scheme (MS). All coauthors contributed to the paper and to the analysis.

Competing interests. The authors declare that they have no conflict of interest.

Acknowledgements. Louis Marelle acknowledges funding from TOTAL SA through an ANRT CIFRE PhD grant. We also acknowledge support from the French Pollution in the Arctic System (PARCS) project funded as part of the French Arctic Initiative by CNRS. We thank Sabine Eckhardt and Marianne T. Lund for providing us the surface measurements of black carbon and sulfate in the Arctic. Computing resources were provided by IDRIS HPC resources (GENCI allocations 2015-017141 and 2016-017141) and the IPSL mesoscale computing center (CICLAD: Calcul Intensif pour le Climat, l'Atmosphère et la Dynamique). Jerome D. Fast, Larry K. Berg, Richard C. Easter, and Manish Shrivastava were supported by the Office of Science of the US Department of Energy as part of the Atmospheric System Research (ASR) program. The Pacific Northwest National Laboratory (PNNL) is operated by DOE by the Battelle Memorial Institute under contract DE-A06-76RLO976 1830.

Edited by: Axel Lauer

Reviewed by: Eric Stofferahn and one anonymous referee

\section{References}

Abbatt, J. P. D., Thomas, J. L., Abrahamsson, K., Boxe, C., Granfors, A., Jones, A. E., King, M. D., Saiz-Lopez, A., Shepson, P. B., Sodeau, J., Toohey, D. W., Toubin, C., von Glasow, R., Wren, S. N., and Yang, X.: Halogen activation via interactions with environmental ice and snow in the polar lower troposphere and other regions, Atmos. Chem. Phys., 12, 6237-6271, https://doi.org/10.5194/acp-12-6237-2012, 2012.

Abdul-Razzak, H. and Ghan, S. J.: A parameterization of aerosol activation: 2. Multiple aerosol types, J. Geophys. Res.-Atmos., 105, 6837-6844, https://doi.org/10.1029/1999JD901161, 2000.

Ahmadov, R., McKeen, S., Trainer, M., Banta, R., Brewer, A., Brown, S., Edwards, P. M., de Gouw, J. A., Frost, G. J., Gilman, J., Helmig, D., Johnson, B., Karion, A., Koss, A., Langford, A., Lerner, B., Olson, J., Oltmans, S., Peischl, J., Pétron, G., Pichugina, Y., Roberts, J. M., Ryerson, T., Schnell, R., Senff, C., Sweeney, C., Thompson, C., Veres, P. R., Warneke, C., Wild, R., Williams, E. J., Yuan, B., and Zamora, R.: Understanding high wintertime ozone pollution events in an oil- and natural gasproducing region of the western US, Atmos. Chem. Phys., 15, 411-429, https://doi.org/10.5194/acp-15-411-2015, 2015.

Alapaty, K., Herwehe, J. A., Otte, T. L., Nolte, C. G., Bullock, O. R., Mallard, M. S., Kain, J. S., and Dudhia, J.: Introducing subgrid-scale cloud feedbacks to radiation for regional meteorological and climate modeling, Geophys. Res. Lett., 39, 124809, https://doi.org/10.1029/2012GL054031, 2012. 
AMAP: AMAP Assessment 2015: Black carbon and ozone as Arctic climate forcers, Tech. rep., Arctic Monitoring and Assessment Programme (AMAP), Oslo, Norway, 2015.

Arnold, S., Law, K., Brock, C., Thomas, J., Starkweather, S., von Salzen, K., Stohl, A., Sharma, S., Lund, M., Flanner, M., Petäjä, T., Tanimoto, H., Gamble, J., Dibb, J., Melamed, M., Johnson, N., Fidel, M., Tynkkynen, V.-P., Baklanov, A., Eckhardt, S., Monks, S., Browse, J., and Bozem, H.: Arctic air pollution: Challenges and opportunities for the next decade, Elementa, 4, 104, https://doi.org/10.12952/journal.elementa.000104, 2016.

Arnold, S. R., Emmons, L. K., Monks, S. A., Law, K. S., Ridley, D. A., Turquety, S., Tilmes, S., Thomas, J. L., Bouarar, I., Flemming, J., Huijnen, V., Mao, J., Duncan, B. N., Steenrod, S., Yoshida, Y., Langner, J., and Long, Y.: Biomass burning influence on high-latitude tropospheric ozone and reactive nitrogen in summer 2008: a multi-model analysis based on POLMIP simulations, Atmos. Chem. Phys., 15, 6047-6068, https://doi.org/10.5194/acp-15-6047-2015, 2015.

Barnard, J. C., Fast, J. D., Paredes-Miranda, G., Arnott, W. P., and Laskin, A.: Technical Note: Evaluation of the WRF-Chem "Aerosol Chemical to Aerosol Optical Properties" Module using data from the MILAGRO campaign, Atmos. Chem. Phys., 10, 7325-7340, https://doi.org/10.5194/acp-10-7325-2010, 2010.

Berg, L. K. and Stull, R. B.: A Simple Parameterization Coupling the Convective Daytime Boundary Layer and Fair-Weather Cumuli, J. Atmos. Sci., 62, 1976-1988, https://doi.org/10.1175/JAS3437.1, 2005.

Berg, L. K., Jr., W. I. G., Kassianov, E. I., and Deng, L.: Evaluation of a Modified Scheme for Shallow Convection: Implementation of CuP and Case Studies, Mon. Weather Rev., 141, 134-147, https://doi.org/10.1175/MWR-D-12-00136.1, 2013.

Berg, L. K., Shrivastava, M., Easter, R. C., Fast, J. D., Chapman, E. G., Liu, Y., and Ferrare, R. A.: A new WRF-Chem treatment for studying regional-scale impacts of cloud processes on aerosol and trace gases in parameterized cumuli, Geosci. Model Dev., 8, 409-429, https://doi.org/10.5194/gmd-8-409-2015, 2015.

Bond, T. C., Doherty, S. J., Fahey, D. W., Forster, P. M., Berntsen, T., DeAngelo, B. J., Flanner, M. G., Ghan, S., Kärcher, B., Koch, D., Kinne, S., Kondo, Y., Quinn, P. K., Sarofim, M. C., Schultz, M. G., Schulz, M., Venkataraman, C., Zhang, H., Zhang, S., Bellouin, N., Guttikunda, S. K., Hopke, P. K., Jacobson, M. Z., Kaiser, J. W., Klimont, Z., Lohmann, U., Schwarz, J. P., Shindell, D., Storelvmo, T., Warren, S. G., and Zender, C. S.: Bounding the role of black carbon in the climate system: A scientific assessment, J. Geophys. Res.-Atmos., 118, 5380-5552, https://doi.org/10.1002/jgrd.50171, 2013.

Boucher, O., Moulin, C., Belviso, S., Aumont, O., Bopp, L., Cosme, E., von Kuhlmann, R., Lawrence, M. G., Pham, M., Reddy, M. S., Sciare, J., and Venkataraman, C.: DMS atmospheric concentrations and sulphate aerosol indirect radiative forcing: a sensitivity study to the DMS source representation and oxidation, Atmos. Chem. Phys., 3, 49-65, https://doi.org/10.5194/acp-3-49-2003, 2003.

Browse, J., Carslaw, K. S., Arnold, S. R., Pringle, K., and Boucher, O.: The scavenging processes controlling the seasonal cycle in Arctic sulphate and black carbon aerosol, Atmos. Chem. Phys., 12, 6775-6798, https://doi.org/10.5194/acp12-6775-2012, 2012.
Carter, W. P. L.: Documentation of the SAPRC-99 chemical mechanism for VOC reactivity assessment. Final Report to California Air Resources Board Contract 92-329 and Contract 95-308, Tech. rep., Air Pollution Research Center and College of Engineering Center for Environmental Research and Technology, University of California Riverside, California, 2000.

Chen, F. and Dudhia, J.: Coupling an Advanced Land SurfaceHydrology Model with the Penn State-NCAR MM5 Modeling System. Part I: Model Implementation and Sensitivity, Mon. Weather Rev., 129, 569-585, https://doi.org/10.1175/15200493(2001)129<0569:CAALSH>2.0.CO;2, 2001.

Chin, M., Jacob, D. J., Gardner, G. M., Foreman-Fowler, M. S., Spiro, P. A., and Savoie, D. L.: A global three-dimensional model of tropospheric sulfate, J. Geophys. Res.-Atmos., 101, 1866718690, https://doi.org/10.1029/96JD01221, 1996.

Chin, M., Ginoux, P., Kinne, S., Torres, O., Holben, B. N., Duncan, B. N., Martin, R. V., Logan, J. A., Higurashi, A., and Nakajima, T.: Tropospheric Aerosol Optical Thickness from the GOCART Model and Comparisons with Satellite and Sun Photometer Measurements, J. Atmos. Sci., 59, 461-483, https://doi.org/10.1175/15200469(2002)059<0461:TAOTFT>2.0.CO;2, 2002.

Eckhardt, S., Quennehen, B., Olivié, D. J. L., Berntsen, T. K., Cherian, R., Christensen, J. H., Collins, W., Crepinsek, S., Daskalakis, N., Flanner, M., Herber, A., Heyes, C., Hodnebrog, Ø., Huang, L., Kanakidou, M., Klimont, Z., Langner, J., Law, K. S., Lund, M. T., Mahmood, R., Massling, A., Myriokefalitakis, S., Nielsen, I. E., Nøjgaard, J. K., Quaas, J., Quinn, P. K., Raut, J.-C., Rumbold, S. T., Schulz, M., Sharma, S., Skeie, R. B., Skov, H., Uttal, T., von Salzen, K., and Stohl, A.: Current model capabilities for simulating black carbon and sulfate concentrations in the Arctic atmosphere: a multi-model evaluation using a comprehensive measurement data set, Atmos. Chem. Phys., 15, 9413-9433, https://doi.org/10.5194/acp-15-9413-2015, 2015

Emmons, L. K., Walters, S., Hess, P. G., Lamarque, J.-F., Pfister, G. G., Fillmore, D., Granier, C., Guenther, A., Kinnison, D., Laepple, T., Orlando, J., Tie, X., Tyndall, G., Wiedinmyer, C., Baughcum, S. L., and Kloster, S.: Description and evaluation of the Model for Ozone and Related chemical Tracers, version 4 (MOZART-4), Geosci. Model Dev., 3, 43-67, https://doi.org/10.5194/gmd-3-43-2010, 2010.

Emmons, L. K., Arnold, S. R., Monks, S. A., Huijnen, V., Tilmes, S., Law, K. S., Thomas, J. L., Raut, J.-C., Bouarar, I., Turquety, S., Long, Y., Duncan, B., Steenrod, S., Strode, S., Flemming, J., Mao, J., Langner, J., Thompson, A. M., Tarasick, D., Apel, E. C., Blake, D. R., Cohen, R. C., Dibb, J., Diskin, G. S., Fried, A., Hall, S. R., Huey, L. G., Weinheimer, A. J., Wisthaler, A., Mikoviny, T., Nowak, J., Peischl, J., Roberts, J. M., Ryerson, T., Warneke, C., and Helmig, D.: The POLARCAT Model Intercomparison Project (POLMIP): overview and evaluation with observations, Atmos. Chem. Phys., 15, 6721-6744, https://doi.org/10.5194/acp-15-6721-2015, 2015.

Fast, J. D., Gustafson, W. I., Easter, R. C., Zaveri, R. A., Barnard, J. C., Chapman, E. G., Grell, G. A., and Peckham, S. E.: Evolution of ozone, particulates, and aerosol direct radiative forcing in the vicinity of Houston using a fully coupled meteorologychemistry-aerosol model, Journal of Geophys. Res.-Atmos., 111, d21305, https://doi.org/10.1029/2005JD006721, 2006. 
Grell, G. A., Peckham, S. E., Schmitz, R., McKeen, S. A., Frost, G., Skamarock, W. C., and Eder, B.: Fully coupled "online" chemistry within the WRF model, Atmos. Environ., 39, 6957-6975, https://doi.org/10.1016/j.atmosenv.2005.04.027, 2005.

Guenther, A., Karl, T., Harley, P., Wiedinmyer, C., Palmer, P. I., and Geron, C.: Estimates of global terrestrial isoprene emissions using MEGAN (Model of Emissions of Gases and Aerosols from Nature), Atmos. Chem. Phys., 6, 3181-3210, https://doi.org/10.5194/acp-6-3181-2006, 2006.

Huang, L., Gong, S. L., Jia, C. Q., and Lavoué, D.: Importance of deposition processes in simulating the seasonality of the Arctic black carbon aerosol, J. Geophys. Res.-Atmos., 115, d17207, https://doi.org/10.1029/2009JD013478, 2010.

Iacono, M. J., Delamere, J. S., Mlawer, E. J., Shephard, M. W., Clough, S. A., and Collins, W. D.: Radiative forcing by longlived greenhouse gases: Calculations with the AER radiative transfer models, J. Geophys. Res.-Atmos., 113, d13103, https://doi.org/10.1029/2008JD009944, 2008.

IPCC: Climate Change 2013: The Physical Science Basis. Contribution of Working Group I to the Fifth Assessment Report of the Intergovernmental Panel on Climate Change, Cambridge University Press, Cambridge, United Kingdom and New York, NY, USA, https://doi.org/10.1017/CBO9781107415324, 2013.

Jacob, D. J., Wofsy, S. C., Bakwin, P. S., Fan, S.-M., Harriss, R. C., Talbot, R. W., Bradshaw, J. D., Sandholm, S. T., Singh, H. B., Browell, E. V., Gregory, G. L., Sachse, G. W., Shipham, M. C., Blake, D. R., and Fitzjarrald, D. R.: Summertime photochemistry of the troposphere at high northern latitudes, J. Geophys. Res.Atmos., 97, 16421-16431, https://doi.org/10.1029/91JD01968, 1992.

Jacob, D. J., Crawford, J. H., Maring, H., Clarke, A. D., Dibb, J. E., Emmons, L. K., Ferrare, R. A., Hostetler, C. A., Russell, P. B., Singh, H. B., Thompson, A. M., Shaw, G. E., McCauley, E., Pederson, J. R., and Fisher, J. A.: The Arctic Research of the Composition of the Troposphere from Aircraft and Satellites (ARCTAS) mission: design, execution, and first results, Atmos. Chem. Phys., 10, 5191-5212, https://doi.org/10.5194/acp10-5191-2010, 2010.

Janjić, Z. I.: The Step-Mountain Eta Coordinate Model: Further Developments of the Convection, Viscous Sublayer, and Turbulence Closure Schemes, Mon. Weather Rev., 122, 927-945, https://doi.org/10.1175/15200493(1994)122<0927:TSMECM>2.0.CO;2, 1994.

Kain, J. S.: The Kain-Fritsch Convective Parameterization: An Update, J. Appl. Meteorol., 43, 170-181, https://doi.org/10.1175/15200450(2004)043<0170:TKCPAU>2.0.CO;2, 2004.

Kain, J. S. and Fritsch, J. M.: A One-Dimensional Entraining/Detraining Plume Model and Its Application in Convective Parameterization, J. Atmos. Sci., 47, 2784-2802, https://doi.org/10.1175/15200469(1990)047<2784:AODEPM>2.0.CO;2, 1990.

Klimont, Z., Kupiainen, K., Heyes, C., Purohit, P., Cofala, J., Rafaj, P., Borken-Kleefeld, J., and Schöpp, W.: Global anthropogenic emissions of particulate matter including black carbon, Atmos. Chem. Phys., 17, 8681-8723, https://doi.org/10.5194/acp-178681-2017, 2017.

Klonecki, A., Hess, P., Emmons, L., Smith, L., Orlando, J., and Blake, D.: Seasonal changes in the transport of pollutants into the
Arctic troposphere-model study, J. Geophys. Res.-Atmos., 108, 8367, https://doi.org/10.1029/2002JD002199, 2003.

Koch, D., Schulz, M., Kinne, S., McNaughton, C., Spackman, J. R., Balkanski, Y., Bauer, S., Berntsen, T., Bond, T. C., Boucher, O., Chin, M., Clarke, A., De Luca, N., Dentener, F., Diehl, T., Dubovik, O., Easter, R., Fahey, D. W., Feichter, J., Fillmore, D., Freitag, S., Ghan, S., Ginoux, P., Gong, S., Horowitz, L., Iversen, T., Kirkevåg, A., Klimont, Z., Kondo, Y., Krol, M., Liu, X., Miller, R., Montanaro, V., Moteki, N., Myhre, G., Penner, J. E., Perlwitz, J., Pitari, G., Reddy, S., Sahu, L., Sakamoto, H., Schuster, G., Schwarz, J. P., Seland, Ø., Stier, P., Takegawa, N., Takemura, T., Textor, C., van Aardenne, J. A., and Zhao, Y.: Evaluation of black carbon estimations in global aerosol models, Atmos. Chem. Phys., 9, 9001-9026, https://doi.org/10.5194/acp-99001-2009, 2009.

Lana, A., Bell, T. G., Simó, R., Vallina, S. M., Ballabrera-Poy, J., Kettle, A. J., Dachs, J., Bopp, L., Saltzman, E. S., Stefels, J., Johnson, J. E., and Liss, P. S.: An updated climatology of surface dimethlysulfide concentrations and emission fluxes in the global ocean, Global Biogeochem. Cy., 25, gB1004, https://doi.org/10.1029/2010GB003850, 2011.

Law, K. S., Stohl, A., Quinn, P. K., Brock, C. A., Burkhart, J. F., Paris, J.-D., Ancellet, G., Singh, H. B., Roiger, A., Schlager, H., Dibb, J., Jacob, D. J., Arnold, S. R., Pelon, J., and Thomas, J. L.: Arctic Air Pollution: New Insights from POLARCAT-IPY, B. Am. Meteorol. Soc., 95, 1873-1895, https://doi.org/10.1175/BAMS-D-13-00017.1, 2014.

Lelieveld, J. and Crutzen, P. J.: Role of Deep Cloud Convection in the Ozone Budget of the Troposphere, Science, 264, 1759-1761, https://doi.org/10.1126/science.264.5166.1759, 1994.

Li, S.-M. and Barrie, L. A.: Biogenic sulfur aerosol in the Arctic troposphere: 1. Contributions to total sulfate, J. Geophys. Res. Atmos., 98, 20613-20622, https://doi.org/10.1029/93JD02234, 1993.

Liu, S. C. and Trainer, M.: Responses of the tropospheric ozone and odd hydrogen radicals to column ozone change, J. Atmos. Chem., 6, 221-233, https://doi.org/10.1007/BF00053857, 1988.

Liu, X., Easter, R. C., Ghan, S. J., Zaveri, R., Rasch, P., Shi, X., Lamarque, J.-F., Gettelman, A., Morrison, H., Vitt, F., Conley, A., Park, S., Neale, R., Hannay, C., Ekman, A. M. L., Hess, P., Mahowald, N., Collins, W., Iacono, M. J., Bretherton, C. S., Flanner, M. G., and Mitchell, D.: Toward a minimal representation of aerosols in climate models: description and evaluation in the Community Atmosphere Model CAM5, Geosci. Model Dev., 5, 709-739, https://doi.org/10.5194/gmd-5-709-2012, 2012.

Ma, P.-L., Rasch, P. J., Wang, H., Zhang, K., Easter, R. C., Tilmes, S., Fast, J. D., Liu, X., Yoon, J.-H., and Lamarque, J.-F.: The role of circulation features on black carbon transport into the Arctic in the Community Atmosphere Model version 5 (CAM5), J.Geophys. Res.-Atmos., 118, 4657-4669, https://doi.org/10.1002/jgrd.50411, 2013.

Ma, P.-L., Rasch, P. J., Fast, J. D., Easter, R. C., Gustafson Jr., W. I., Liu, X., Ghan, S. J., and Singh, B.: Assessing the CAM5 physics suite in the WRF-Chem model: implementation, resolution sensitivity, and a first evaluation for a regional case study, Geosci. Model Dev., 7, 755-778, https://doi.org/10.5194/gmd-7755-2014, 2014.

Mahmood, R., von Salzen, K., Flanner, M., Sand, M., Langner, J., Wang, H., and Huang, L.: Seasonality of 
global and Arctic black carbon processes in the Arctic Monitoring and Assessment Programme models, Journal of Geophysical Research: Atmospheres, 121, 7100-7116, https://doi.org/10.1002/2016JD024849, 2016.

Marelle, L., Raut, J.-C., Thomas, J. L., Law, K. S., Quennehen, B., Ancellet, G., Pelon, J., Schwarzenboeck, A., and Fast, J. D.: Transport of anthropogenic and biomass burning aerosols from Europe to the Arctic during spring 2008, Atmos. Chem. Phys., 15, 3831-3850, https://doi.org/10.5194/acp15-3831-2015, 2015.

Marelle, L., Thomas, J. L., Raut, J.-C., Law, K. S., Jalkanen, J.P., Johansson, L., Roiger, A., Schlager, H., Kim, J., Reiter, A., and Weinzierl, B.: Air quality and radiative impacts of Arctic shipping emissions in the summertime in northern Norway: from the local to the regional scale, Atmos. Chem. Phys., 16, 23592379, https://doi.org/10.5194/acp-16-2359-2016, 2016.

Matsui, H., Kondo, Y., Moteki, N., Takegawa, N., Sahu, L. K., Zhao, Y., Fuelberg, H. E., Sessions, W. R., Diskin, G., Blake, D. R., Wisthaler, A., and Koike, M.: Seasonal variation of the transport of black carbon aerosol from the Asian continent to the Arctic during the ARCTAS aircraft campaign, J. Geophys. Res.-Atmos., 116, d05202, https://doi.org/10.1029/2010JD015067, 2011.

Mölders, N., Porter, S. E., Cahill, C. F., and Grell, G. A.: Influence of ship emissions on air quality and input of contaminants in southern Alaska National Parks and Wilderness Areas during the 2006 tourist season, Atmos. Environ., 44, 1400-1413, https://doi.org/10.1016/j.atmosenv.2010.02.003, 2010.

Monks, S. A., Arnold, S. R., Emmons, L. K., Law, K. S., Turquety, S., Duncan, B. N., Flemming, J., Huijnen, V., Tilmes, S., Langner, J., Mao, J., Long, Y., Thomas, J. L., Steenrod, S. D., Raut, J. C., Wilson, C., Chipperfield, M. P., Diskin, G. S., Weinheimer, A., Schlager, H., and Ancellet, G.: Multi-model study of chemical and physical controls on transport of anthropogenic and biomass burning pollution to the Arctic, Atmos. Chem. Phys., 15, 3575-3603, https://doi.org/10.5194/acp-15-3575-2015, 2015.

Morrison, H., Thompson, G., and Tatarskii, V.: Impact of Cloud Microphysics on the Development of Trailing Stratiform Precipitation in a Simulated Squall Line: Comparison of One- and Two-Moment Schemes, Mon. Weather Rev., 137, 991-1007, https://doi.org/10.1175/2008MWR2556.1, 2009.

Nightingale, P. D., Malin, G., Law, C. S., Watson, A. J., Liss, P. S., Liddicoat, M. I., Boutin, J., and Upstill-Goddard, R. C.: In situ evaluation of air-sea gas exchange parameterizations using novel conservative and volatile tracers, Global Biogeochem. Cy., 14, 373-387, https://doi.org/10.1029/1999GB900091, 2000.

Quinn, P. K., Shaw, G., Andrews, E., Dutton, E. G., Ruoho-Airola, T., and Gong, S. L.: Arctic haze: current trends and knowledge gaps, Tellus B, 59, 99-114, https://doi.org/10.1111/j.16000889.2006.00238.x, 2007.

Rahn, K. A.: Arctic Air Chemistry Proceedings of the Second Symposium Relative importances of North America and Eurasia as sources of arctic aerosol, Atmos. Environ., 15, 1447-1455, https://doi.org/10.1016/0004-6981(81)90351-6, 1981.

Raut, J.-C., Marelle, L., Fast, J. D., Thomas, J. L., Weinzierl, B., Law, K. S., Berg, L. K., Roiger, A., Easter, R. C., Heimerl, K., Onishi, T., Delanoë, J., and Schlager, H.: Cross-polar transport and scavenging of Siberian aerosols containing black carbon during the 2012 ACCESS summer campaign, Atmos. Chem.
Phys., 17, 10969-10995, https://doi.org/10.5194/acp-17-109692017, 2017.

Riahi, K., Rao, S., Krey, V., Cho, C., Chirkov, V., Fischer, G., Kindermann, G., Nakicenovic, N., and Rafaj, P.: RCP 8.5 - A scenario of comparatively high greenhouse gas emissions, Climatic Change, 109, 33-57, https://doi.org/10.1007/s10584-011-0149y, 2011.

Robinson, A. L., Donahue, N. M., Shrivastava, M. K., Weitkamp, E. A., Sage, A. M., Grieshop, A. P., Lane, T. E., Pierce, J. R., and Pandis, S. N.: Rethinking Organic Aerosols: Semivolatile Emissions and Photochemical Aging, Science, 315, 1259-1262, https://doi.org/10.1126/science.1133061, 2007.

Saltzman, E. S., King, D. B., Holmen, K., and Leck, C.: Experimental determination of the diffusion coefficient of dimethylsulfide in water, J. Geophys. Res.-Oceans, 98, 16481-16486, https://doi.org/10.1029/93JC01858, 1993.

Sato, Y., Miura, H., Yashiro, H., Goto, D., Takemura, T., Tomita, H., and Nakajima, T.: Unrealistically pristine air in the Arctic produced by current global scale models, Scientific Reports, 6, p. 26561, 2016.

Schwarz, J. P., Spackman, J. R., Gao, R. S., Watts, L. A., Stier, P., Schulz, M., Davis, S. M., Wofsy, S. C., and Fahey, D. W.: Global-scale black carbon profiles observed in the remote atmosphere and compared to models, Geophys. Res. Lett., 37, 118812, https://doi.org/10.1029/2010GL044372, 2010.

Schwarz, J. P., Weinzierl, B., Samset, B. H., Dollner, M., Heimerl, K., Markovic, M. Z., Perring, A. E., and Ziemba, L.: Aircraft measurements of black carbon vertical profiles show upper tropospheric variability and stability, Geophys. Res. Lett., 44, 11321140, https://doi.org/10.1002/2016GL071241, 2017.

Sessions, W. R., Fuelberg, H. E., Kahn, R. A., and Winker, D. M.: An investigation of methods for injecting emissions from boreal wildfires using WRF-Chem during ARCTAS, Atmos. Chem. Phys., 11, 5719-5744, https://doi.org/10.5194/acp-115719-2011, 2011.

Shindell, D., Faluvegi, G., Lacis, A., Hansen, J., Ruedy, R., and Aguilar, E.: Role of tropospheric ozone increases in 20thcentury climate change, J. Geophys. Res.-Atmos., 111, d08302, https://doi.org/10.1029/2005JD006348, 2006.

Shindell, D. T., Chin, M., Dentener, F., Doherty, R. M., Faluvegi, G., Fiore, A. M., Hess, P., Koch, D. M., MacKenzie, I. A., Sanderson, M. G., Schultz, M. G., Schulz, M., Stevenson, D. S., Teich, H., Textor, C., Wild, O., Bergmann, D. J., Bey, I., Bian, H., Cuvelier, C., Duncan, B. N., Folberth, G., Horowitz, L. W., Jonson, J., Kaminski, J. W., Marmer, E., Park, R., Pringle, K. J., Schroeder, S., Szopa, S., Takemura, T., Zeng, G., Keating, T. J., and Zuber, A.: A multi-model assessment of pollution transport to the Arctic, Atmos. Chem. Phys., 8, 5353-5372, https://doi.org/10.5194/acp-8-5353-2008, 2008.

Shrivastava, M., Fast, J., Easter, R., Gustafson Jr., W. I., Zaveri, R. A., Jimenez, J. L., Saide, P., and Hodzic, A.: Modeling organic aerosols in a megacity: comparison of simple and complex representations of the volatility basis set approach, Atmos. Chem. Phys., 11, 6639-6662, https://doi.org/10.5194/acp11-6639-2011, 2011.

Simpson, W. R., von Glasow, R., Riedel, K., Anderson, P., Ariya, P., Bottenheim, J., Burrows, J., Carpenter, L. J., Frieß, U., Goodsite, M. E., Heard, D., Hutterli, M., Jacobi, H.-W., Kaleschke, L., Neff, B., Plane, J., Platt, U., Richter, A., Roscoe, H., Sander, R., 
Shepson, P., Sodeau, J., Steffen, A., Wagner, T., and Wolff, E.: Halogens and their role in polar boundary-layer ozone depletion, Atmos. Chem. Phys., 7, 4375-4418, https://doi.org/10.5194/acp7-4375-2007, 2007.

Skamarock, W. C., Klemp, J., Dudhia, J., Gill, D., Barker, D., Duda, M., Huang, X., Wang, W., and Powers., J.: A description of the Advanced Research WRF Version 3, Tech. rep., NCAR, 2008.

Stohl, A.: Characteristics of atmospheric transport into the Arctic troposphere, J. Geophys. Res.-Atmos., 111, d11306, https://doi.org/10.1029/2005JD006888, 2006.

Stohl, A., Klimont, Z., Eckhardt, S., Kupiainen, K., Shevchenko, V. P., Kopeikin, V. M., and Novigatsky, A. N.: Black carbon in the Arctic: the underestimated role of gas flaring and residential combustion emissions, Atmos. Chem. Phys., 13, 8833-8855, https://doi.org/10.5194/acp-13-8833-2013, 2013.

Stohl, A., Aamaas, B., Amann, M., Baker, L. H., Bellouin, N., Berntsen, T. K., Boucher, O., Cherian, R., Collins, W., Daskalakis, N., Dusinska, M., Eckhardt, S., Fuglestvedt, J. S., Harju, M., Heyes, C., Hodnebrog, Ø., Hao, J., Im, U., Kanakidou, M., Klimont, Z., Kupiainen, K., Law, K. S., Lund, M. T., Maas, R., MacIntosh, C. R., Myhre, G., Myriokefalitakis, S., Olivié, D., Quaas, J., Quennehen, B., Raut, J.-C., Rumbold, S. T., Samset, B. H., Schulz, M., Seland, Ø., Shine, K. P., Skeie, R. B., Wang, S., Yttri, K. E., and Zhu, T.: Evaluating the climate and air quality impacts of short-lived pollutants, Atmos. Chem. Phys., 15, 10529-10566, https://doi.org/10.5194/acp-15-105292015, 2015.

Tanskanen, A. and Manninen, T.: Effective UV surface albedo of seasonally snow-covered lands, Atmos. Chem. Phys., 7, 27592764, https://doi.org/10.5194/acp-7-2759-2007, 2007.

Tegen, I. and Fung, I.: Modeling of mineral dust in the atmosphere: Sources, transport, and optical thickness, J. Geophys. Res.Atmos., 99, 22897-22914, https://doi.org/10.1029/94JD01928, 1994.

Thomas, J. L., Raut, J.-C., Law, K. S., Marelle, L., Ancellet, G., Ravetta, F., Fast, J. D., Pfister, G., Emmons, L. K., Diskin, G. S., Weinheimer, A., Roiger, A., and Schlager, H.: Pollution transport from North America to Greenland during summer 2008, Atmos. Chem. Phys., 13, 3825-3848, https://doi.org/10.5194/acp13-3825-2013, 2013.
Wang, H., Easter, R. C., Rasch, P. J., Wang, M., Liu, X., Ghan, S. J., Qian, Y., Yoon, J.-H., Ma, P.-L., and Vinoj, V.: Sensitivity of remote aerosol distributions to representation of cloud-aerosol interactions in a global climate model, Geosci. Model Dev., 6, 765-782, https://doi.org/10.5194/gmd-6-765-2013, 2013.

Wang, Q., Jacob, D. J., Spackman, J. R., Perring, A. E., Schwarz, J. P., Moteki, N., Marais, E. A., Ge, C., Wang, J., and Barrett, S. R. H.: Global budget and radiative forcing of black carbon aerosol: Constraints from pole-to-pole (HIPPO) observations across the Pacific, J. Geophys. Res.-Atmos., 119, 195-206, https://doi.org/10.1002/2013JD020824, 2014.

Wesely, M.: Parameterization of surface resistances to gaseous dry deposition in regional-scale numerical models, Atmos. Environ., 23, 1293-1304, https://doi.org/10.1016/0004-6981(89)90153-4, 1989.

Wiedinmyer, C., Yokelson, R. J., and Gullett, B. K.: Global Emissions of Trace Gases, Particulate Matter, and Hazardous Air Pollutants from Open Burning of Domestic Waste, Environ. Sci. Technol., 48, 9523-9530, https://doi.org/10.1021/es502250z, 2014.

Wild, O., Zhu, X., and Prather, M. J.: Fast-J: Accurate Simulation of In- and Below-Cloud Photolysis in Tropospheric Chemical Models, J. Atmos. Chem., 37, 245-282, https://doi.org/10.1023/A:1006415919030, 2000.

Wong, J., Barth, M. C., and Noone, D.: Evaluating a lightning parameterization based on cloud-top height for mesoscale numerical model simulations, Geosci. Model Dev., 6, 429-443, https://doi.org/10.5194/gmd-6-429-2013, 2013.

Zaveri, R. A., Easter, R. C., Fast, J. D., and Peters, L. K.: Model for Simulating Aerosol Interactions and Chemistry (MOSAIC), J. Geophys. Res.-Atmos., 113, d13204, https://doi.org/10.1029/2007JD008782, 2008. 